\title{
Statistical Evaluation of an Electrochemical Probe for the Detection of Chlorate
}

\author{
Scott A. Trammell,* Lisa C. Shriver-Lake, and Walter J. Dressick* \\ US Naval Research Laboratory \\ Center for Bio/Molecular Science \& Engineering (Code 6900) \\ 4555 Overlook Avenue SW \\ Washington, DC 20375 USA \\ E-mail: scott.trammell@nrl.navy.mil \\ walter.dressick@nrl.navy.mil
}

\begin{abstract}
We describe the use and characterization of a multilayer film, prepared via layer-by-layer deposition of cationic para-rosaniline acetate dye (i.e., PR) and the vanadium-containing Keggintype polyoxometalate anion, $\left[\mathrm{PMo}_{11} \mathrm{VO}_{40}\right]^{5-}$ (i.e., $\mathrm{PVMo} 11$ ), on indium tin oxide (ITO) as an electrode for determination of chlorate. A linear cyclic voltammetry $(\mathrm{CV})$ current response was observed for the $0 \mu \mathrm{M} \leq\left[\mathrm{ClO}_{3}{ }^{-}\right] \leq 1000 \mu \mathrm{M}$ range with a detection limit of $\sim 220 \mu \mathrm{M} \mathrm{ClO}_{3}{ }^{-}(\mathrm{S} / \mathrm{N}$ $>3$ ) in a $\mathrm{pH}=2.5$ solution of $100 \mathrm{mM}$ sodium acetate. Electrode response was insensitive to interference by oxygen and nitrogen-based explosives like TNT, a prerequisite for use in the field. A Taguchi L16 array was used to investigate the performance of the electrode as functions of number of $\mathrm{PVMo}_{11} / \mathrm{PR}$ bilayers ( $\mathbf{L} ; 3-6$ bilayers), solution $\mathrm{pH}(\mathbf{H} ; \mathrm{pH} \sim 1.32-2.85)$, solution $\left[\mathrm{ClO}_{3}{ }^{-}\right](\mathbf{C} ; 250-1000 \mu \mathrm{M}), \mathrm{CV}$ scan rate $\left(\mathbf{S} ; 50-200 \mathrm{mV} \cdot \mathrm{s}^{-1}\right)$, and film age $(\mathbf{A} ; 1-8$ weeks $)$. Maximum current response was obtained for a 1 week old 5 bilayer film immersed in a pH 2.85 $0.10 \mathrm{M} \mathrm{NaCl}(\mathrm{aq})$ solution containing $1000 \mu \mathrm{M} \mathrm{ClO}_{3}{ }^{-}$. However, current response fell as films aged, requiring aging of films for approximately 8 weeks prior to use to obtain reproducible analyses. A two-level full factorial design using films aged 8 weeks identified the variables $\mathbf{S}, \mathbf{L}$, $\mathbf{H}$, and $\mathbf{C}$ and variable interactions $\mathbf{L S}$ and $\mathbf{H S}$ as statistically significant contributors to the film current response and provided a model describing film performance.
\end{abstract}

Keywords: chlorate detection; electrocatalysis; polyoxometalates; layer-by-layer assembly; statistically designed experiments 


\subsection{Introduction}

The manufacture and use of improvised explosive devices (IEDs) presents a serious hazard to military and civilian personnel in conflict zones throughout the world. Consequently, it is critically important to be able to identify and dismantle manufacturing sites for these devices before they can be fabricated and deployed. A key element in this strategy is the remote, surreptitious detection of the presence of residual explosive components at or near the sites, providing confirmation of illicit activity and allowing authorities to coordinate efforts to identify and detain persons associated with IED manufacture. As current detection methods for readily available nitrogen-based explosives continue to evolve in terms of sensitivity and selectivity, [15] enemy combatants are increasingly turning to alternate explosives based on chlorate or peroxides, for which fewer means of reliable detection in the field are available.

In particular, chlorate detection is complicated by a complex $\mathrm{pH}$-dependent redox chemistry that facilitates (inter)conversion of chlorate to other chlorine-containing species such as hypochlorite, chlorite, chlorine dioxide, chlorine, and chloride [6-8]. Ion exchange chromatography provides a means for rapid separation of such Cl-containing species and, coupled with sensitive mass spectrometric detection, permits quantitative determination of each species in a laboratory setting $[9,10]$. However, carrying out such an analysis in the field, where rapid determinations must be made under often adverse conditions, presents serious logistical issues, especially in terms of safety, weight, and power requirements.

Simpler spectrophotometric methods for chlorate detection are, in theory, amenable for field use. These methods are generally based on bleaching the color of a dye species $[6,11-14]$ or the catalyzed generation of colored triiodide anion [15-18] in the presence of chlorate. The color change may be visible to the naked eye or with the aid of very simple instrumentation, permitting development of a lightweight system that requires little or no power to operate. However, specificity for chlorate detection generally remains an issue, since various other chlorine species such as hypochlorite, chlorite, chlorine, and chlorine dioxide are also strong oxidants capable of interfering and rendering a false positive signal.

Electrochemical methods that exploit the redox behavior of the chlorate species provide a more convenient alternative to spectrophotometric detection methods. While electrochemical methods do require a power source, recent advances in electronics miniaturization and design can now provide lightweight, low-cost, rugged, low power potentiostats [19] that limit the impact of this issue. Because a simpler "yes or no" determination, rather than a quantitative chlorate analysis, may be sufficient for on-site testing in the field, any sensitivity issues related to the use of these simpler instruments are less of a concern. There are, however, several other issues associated with electrochemical detection of chlorate that must be addressed, especially for field work.

First among these is electrode type. Previous systems for analysis of chlorate were based primarily upon polarographic and related techniques using Hg electrodes, [20-25] which are not ideal for field use. During the 1990s, Gao and coworkers [26-30] extended earlier work by Unoura [31] and others [32, 33] demonstrating catalytic electroreduction of chlorate by polyoxometalates and related transition metal compounds in solution at $\mathrm{Pt}$ and glassy carbon electrodes by developing electrocatalytic carbon paste electrodes impregnated with carboxylate 
ligand species and polyoxometalates as chlorate sensors. More recently, Jakmunee and coworkers [34] demonstrated amperometric detection of chlorate using a triiodide based scheme with stopped-flow injection, which was subsequently used for successful detection of chlorate in soil samples [35].

A second issue is the potential interference due to electrochemical signatures of other chlorinecontaining species, such as hypochlorite, chlorite, and chlorine dioxide, which may be present with chlorate or generated from it during the course of sampling and analysis. Fortunately, significant efforts and progress have been made to address this concern. For example, rather than detect chlorate directly, Wen and coworkers [36] utilize it to selectively oxidize chalcopyrite (i.e., $\mathrm{CuFeS}_{2}$ ) and electrochemically detect the $\mathrm{Cu}$ (II) and $\mathrm{Fe}(\mathrm{III})$ released. Similar strategies have been demonstrated using sphalerite (i.e., $\mathrm{ZnS}_{2}$, producing $\mathrm{Zn}(\mathrm{II})$ )[37] and galena (i.e., $\mathrm{PbS}$, producing $\mathrm{Pb}(\mathrm{II})$ ) [38] as the metal ion sources. Elimination of Cl-containing interferences can also be accomplished via their preferential removal from a sample by reaction with $\mathrm{N}_{2} \mathrm{H}_{5}{ }^{+} / \mathrm{OsO}_{4}$ [39], $\mathrm{BH}_{4}^{-}$[40], or $\mathrm{Fe}(\mathrm{II})$ [6] and/or careful adjustment of the reaction conditions $[41,42]$ prior to initiating the electrochemical analysis of chlorate. Finally, recent work indicates that selective surface modification of the electrode with rare earth coatings [43, 44] can hinder the reduction of certain Cl-containing species, such as hypochlorite, in the presence of chlorate.

Despite these advancements, the electrochemical analysis of chlorate under ambient conditions in the field remains hindered by the presence of oxygen, whose reduction $\left(\mathrm{E}_{\mathrm{pc}}>-0.3 \mathrm{~V}\right.$. vs. $\mathrm{Ag} / \mathrm{AgCl})$ is sufficiently close to that of electrocatalytic reduction of chlorate $\left(\mathrm{E}_{\mathrm{pc}} \cong-0.4 \mathrm{~V}\right.$. vs. $\mathrm{Ag} / \mathrm{AgCl}$ ) that it interferes with the analysis. Although the $\mathrm{pH}$ dependence of the oxygen reduction potential can be exploited to lessen this effect, it cannot be entirely removed. In similar fashion, any attempt to deconvolute measured current data to account for the oxygen contribution requires simultaneous measurement of the oxygen level and introduces additional complexity and error sources into the analysis. Removal of oxygen from the sample by purging with inert gas can certainly solve the problem, but at the expense of longer analysis times and added inert gas container weight, both of which are problematic for field use. There is clearly a need for an electrode that senses chlorate directly under ambient conditions from real world samples, such as soil, that may also be contaminated with traces of other electroactive species, such as humates, metal ions, and nitrogen-based explosives, among others.

Recently Fernandes, et. al. [45] described a composite electrode prepared via layer by layer (LbL) alternate electrostatic deposition of the Keggin-type polyoxometalate anion, $\left[\mathrm{PMo}_{11} \mathrm{VO}_{40}\right]^{5-}\left(\mathrm{PMo}_{11} \mathrm{~V}\right)$, and the cationic dye, $p$-rosaniline acetate (PR) (note Scheme 1). The resulting stable electrode films were permeable to large anions, such as ferrocyanide, and exhibited electrocatalytic oxidation of ascorbate and reduction of iodate. The observation of four reversible one-electron waves in the cyclic voltammograms of the films at $\mathrm{E}_{\mathrm{pc} 1}=0.367 \mathrm{~V}(\mathrm{~V}$ based), $\mathrm{E}_{\mathrm{pc} 2}=0.098 \mathrm{~V}$ (Mo-based), $\mathrm{E}_{\mathrm{pc} 3}=-0.122 \mathrm{~V}$ (Mo-based), and $\mathrm{E}_{\mathrm{pc} 4}=-0.266 \mathrm{~V}$ (Mobased) vs. $\mathrm{Ag} / \mathrm{AgCl}$ prompted us to test the ability of these electrodes to efficiently reduce chlorate. To our delight, electrocatalytic waves for the reduction of chlorate were observed using these electrodes under ambient conditions with no detectable interference from oxygen. We describe here the preparation and characterization of our electrode system with respect to the factors electrode film age (A), solution acidity/pH (H), cyclic voltammetry (CV) scan speed (S), 
chlorate concentration $(\mathbf{C})$, and number of $\mathrm{PMo}_{11} \mathrm{~V} / \mathrm{PR}$ bilayers $(\mathbf{L})$ present in the electrode film. Electrode performance was optimized using a Taguchi L16 array and a two-level full factorial design provides a model predicting current for the detection of chlorate as a function of these parameters.

\subsection{Material and Methods}

\subsection{Materials}

Ultrapure water of $18.2 \mathrm{M} \Omega \cdot \mathrm{cm}^{-1}$ resistivity obtained from a Milli-Q Advantage deionized water system was use to prepare all solutions and for all experiments. Filtered $\mathrm{N}_{2}$ gas from liquid $\mathrm{N}_{2}$ boil-off was used for drying samples during film deposition. All chemicals were used as received except where otherwise noted. Branched polyethylenimine (PEI; 50\% wt. solution in water; $M_{n}=60,000 ; M_{w}=750,000 ;$ [9002-98-6]), para-rosaniline acetate (PR; 90\% dye; 347.41 $\mathrm{g} \cdot \mathrm{mole}^{-1} ;[6035-94-5] ; \varepsilon_{540 \mathrm{~nm}}=6.19 \times 10^{4} \mathrm{~L} \cdot \mathrm{mole}^{-1} \cdot \mathrm{cm}^{-1} ;$ Caution- cancer suspect agent $)$, vanadium (IV) oxide sulfate tetrahydrate $\left(\mathrm{VOSO}_{4} \cdot 4 \mathrm{H}_{2} \mathrm{O} ; 97 \% ; 235.04 \mathrm{~g} \cdot \mathrm{mole}^{-1} ;\right.$ [123334-20-3]), sodium dihydrogen phosphate $\left(\mathrm{NaH}_{2} \mathrm{PO}_{4} ; \geq 99.99 \% ; 119.98 \mathrm{~g} \cdot \mathrm{mole}{ }^{-1}\right.$; [7558-80-7]), sodium acetate $\left(\mathrm{NaOAc} ; \geq 99.0 \% ; 82.03 \mathrm{~g} \cdot \mathrm{mole}^{-1} ;\right.$ [127-09-3]), potassium chlorate $\left(\mathrm{KClO}_{3} ; \geq 99.0 \%\right.$; $122.55 \mathrm{~g} \cdot \mathrm{mole}^{-1}$; [3811-04-9]; Caution- strong oxidizer), glacial acetic acid (HOAc; $\geq 99.7 \%$; $60.05 \mathrm{~g} \cdot \mathrm{mole}^{-1} ; \rho=1.049 \mathrm{~g} \cdot \mathrm{mL}^{-1}$; [64-19-7]), methanol $\left(\mathrm{CH}_{3} \mathrm{OH} ; \geq 99.0 \%\right.$; $32.04 \mathrm{~g} \cdot \mathrm{mole}^{-1}$; [6756-1]), and sodium chloride $\left(\mathrm{NaCl} ; \geq 99.99 \% ; 58.44 \mathrm{~g} \cdot \mathrm{mole}^{-1} ;\right.$ [7647-14-5]) were all from Sigma-Aldrich Chemicals. $N$-(2-aminoethyl)-3-aminopropyltrimethoxysilane (DAMO; 95\% technical grade; $226.36 \mathrm{~g} \cdot \mathrm{mole}^{-1} ; \rho=1.019 \mathrm{~g} \cdot \mathrm{mL}^{-1} ;$ [1760-24-3]) from Gelest Inc. was vacuum distilled $\left(140^{\circ} \mathrm{C}, 15 \mathrm{~mm} \mathrm{Hg}\right)$ immediately prior to use. Sodium molybdate dihydrate $\left(\mathrm{Na}_{2} \mathrm{MoO}_{4} \cdot 2 \mathrm{H}_{2} \mathrm{O} ; 99 \% ; 241.95 \mathrm{~g} \cdot \mathrm{mole}^{-1}\right.$; [10102-40-6]) was obtained from Strem Chemicals. Concentrated hydrochloric acid $\left(\mathrm{HCl} ; 36.46 \mathrm{~g} \cdot \mathrm{mole}^{-1}\right.$; [7647-01-0]) and sulfuric acid $\left(\mathrm{H}_{2} \mathrm{SO}_{4}\right.$; $98.18 \mathrm{~g} \cdot \mathrm{mole}^{-1}$; [7664-93-9]) were both ACS Reagent Grade from Fisher Scientific. Quartz slides $(50 \mathrm{~mm} \times 25 \mathrm{~mm} \times 1 \mathrm{~mm})$ were purchased from Dell Optics, Orange, NJ and indium tin oxide (ITO) slides (part no. CB-50IN-S111), each bearing an ITO coating $\left(\mathrm{R}_{\mathrm{s}}=5-15 \Omega\right)$ on one side of a piece of Corning $1737 \mathrm{~F}$ aluminosilicate glass $(75 \mathrm{~mm} \times 25 \mathrm{~mm} \times 1.1 \mathrm{~mm})$, were from Delta Technologies Limited, Stillwater, MN.

$\mathrm{Na}_{4} \mathrm{H}\left[\left(\mathrm{VMo}_{11}\right) \mathrm{O}_{40}\right]$ (i.e., $\mathrm{PMo}_{11} \mathrm{~V} ; 1839.21 \mathrm{~g} \cdot \mathrm{mole}^{-1}$ ) was prepared at reduced scale with some modification of the literature method [46] as follows: A solution of $0.44 \mathrm{~g} \mathrm{VOSO}_{4} \cdot 4 \mathrm{H}_{2} \mathrm{O}$ in $9 \mathrm{~mL}$ $0.10 \mathrm{M} \mathrm{HCl}(\mathrm{aq})$ solution was freshly prepared. A second solution containing $0.054 \mathrm{~g} \mathrm{NaH}_{2} \mathrm{PO}_{4}$ and $1.21 \mathrm{~g} \mathrm{Na}_{2} \mathrm{MoO}_{4} \cdot 2 \mathrm{H}_{2} \mathrm{O}$ in $20 \mathrm{~mL}$ water was then prepared. The $\mathrm{VOSO}_{4}$ solution was added to the well stirred $\mathrm{NaH}_{2} \mathrm{PO}_{4} / \mathrm{Na}_{2} \mathrm{MoO}_{4} \cdot 2 \mathrm{H}_{2} \mathrm{O}$ solution. The stirred blue-black solution (characteristic of the $\mathrm{V}^{\mathrm{IV}}$ form of the product) [46] formed was titrated with $3.0 \mathrm{M} \mathrm{HCl}$ (aq) dropwise to $\mathrm{pH} 3.5$ using a $\mathrm{pH}$ meter. After stirring at room temperature for $30 \mathrm{~min}$, the blueblack solution was quickly frozen at $-20^{\circ} \mathrm{C}$ for $90 \mathrm{~min}$ in a freezer and transferred to a freeze dryer. After freeze drying for 4 days the water had been removed, leaving $1.53 \mathrm{~g}$ of a gray-black solid that dissolves readily in water to form a dark blue solution that slowly becomes orangebrown in color. The gray-black solid was used immediately for film depositions, but can also be stored in the $-20^{\circ} \mathrm{C}$ freezer with no apparent change in color by eye for at least 4 months. 
Stock PEI ( $\sim 5 \mathrm{mg} / \mathrm{mL})$ solution was freshly prepared just prior to use by weighing $1.0 \mathrm{~g} 50 \%$ wt. PEI (aq) solution into a tared $125 \mathrm{~mL}$ Ehrlenmeyer flask, adding sufficient water to bring the total solution weight to $100 \mathrm{~g}$, and carefully stirring the mixture until the PEI had completely dissolved. A $0.10 \mathrm{M} \mathrm{HOAc}(\mathrm{aq})$ solution was prepared by pipetting $2.90 \mathrm{~mL}$ HOAc into a 500 $\mathrm{mL}$ volumetric flask containing $100 \mathrm{~mL}$ water and diluting to the mark with water. A $0.10 \mathrm{M}$ $\mathrm{NaOAc}$ (aq) solution was prepared by quickly weighing $0.820 \mathrm{~g}$ anhydrous NaOAc into a 100 $\mathrm{mL}$ volumetric flask, adding $\sim 30 \mathrm{~mL}$ water to dissolve the solid, and diluting to the mark with water. Stock $0.10 \mathrm{M}$ acetate buffer $\mathrm{pH} 4$ was prepared by pipetting $90.00 \mathrm{~mL}$ of the $0.10 \mathrm{M}$ $\mathrm{NaOAc}$ (aq) solution into a $500 \mathrm{~mL}$ volumetric flask and diluting to the mark using the $0.10 \mathrm{M}$ HOAc (aq) solution. Stock $0.14 \mathrm{mM}$ PR solution was prepared by weighing $5.3 \mathrm{mg}$ of PR into a $100 \mathrm{~mL}$ volumetric flask and diluting to the mark with stock $0.10 \mathrm{M}$ acetate buffer $\mathrm{pH}$ 4. Stock $\mathrm{PMo}_{11} \mathrm{~V}(2 \mathrm{mg} / \mathrm{mL} \cong 1.09 \mathrm{mM})$ solution was freshly prepared immediately prior to use by dissolving $22 \mathrm{mg}$ of $\mathrm{Na}_{4} \mathrm{H}\left[\left(\mathrm{VMo}_{11}\right) \mathrm{O}_{40}\right]$ solid in $11 \mathrm{~mL}$ of the $0.10 \mathrm{M}$ acetate buffer $\mathrm{pH} 4$.

Chlorate-containing solutions for initial experiments were prepared by dissolving appropriate quantities of $\mathrm{KClO}_{3}$ in a $100 \mathrm{mM}$ sodium acetate solution whose $\mathrm{pH}$ had been adjusted to $\mathrm{pH}$ $\sim 2.5$ using hydrochloric acid. Chlorate-containing solutions having $\mu=0.10 \mathrm{M}$ total ionic strength for electrochemical studies were prepared from the following stock solutions: Solution A (0.095 M NaCl (aq)) prepared by dissolving $1.388 \mathrm{~g} \mathrm{NaCl}$ in water in a $250 \mathrm{~mL}$ volumetric flask and diluting to the mark with water. Solution B $(0.100 \mathrm{M} \mathrm{NaCl}(\mathrm{aq}))$ was prepared by dissolving $5.844 \mathrm{~g} \mathrm{NaCl}$ in water in a $1 \mathrm{~L}$ volumetric flask and diluting to the mark with water. Solution C (0.0625 M HCl (aq) / $0.0375 \mathrm{M} \mathrm{NaCl}(\mathrm{aq}))$ was prepared by dissolving $1.096 \mathrm{~g} \mathrm{NaCl}$ in $\sim 100 \mathrm{~mL}$ water in a $500 \mathrm{~mL}$ volumetric flask, adding $2.60 \mathrm{~mL}$ concentrated $\mathrm{HCl}$ by pipet, and diluting to the mark with water. These stock solutions were prepared and stored until needed for experiments. Solution $\mathrm{D}\left(0.005 \mathrm{M} \mathrm{KClO}_{3}\left(\mathrm{KClO}_{3}(\mathrm{aq}) / 0.095 \mathrm{M} \mathrm{NaCl}(\mathrm{aq})\right)\right.$ was freshly prepared each day by weighing $61.3 \mathrm{mg} \mathrm{KClO}_{3}$ into a $100 \mathrm{~mL}$ volumetric flask, dissolving the solid in $\sim 30 \mathrm{~mL}$ Solution A, and diluting to the mark with Solution A. Chlorate-containing solutions with specific $\mathrm{pH}$ and $\left[\mathrm{KClO}_{3}\right]$ values for electrochemical studies were prepared by mixing Solutions B, C, and D in the appropriate ratios. Corresponding blank solutions used to equilibrate the multilayers on ITO with the corresponding $\mathrm{pH}$ solution were prepared by replacing Solution D in each formulation by an equivalent volume of Solution B. The multilayers on ITO were equilibrated by 4 successive CV sweeps in the absence of chlorate.

\subsection{Instruments and Measurements}

Solution $\mathrm{pH}$ values were measured using a Corning Pinnacle $530 \mathrm{pH}$ meter equipped with an AccuTupH+ pH electrode (cat. no. 13-620-185). UV-visible spectra were measured using a double beam Varian Cary 5000 spectrophotometer. Spectra of $\mathrm{PMo}_{11} \mathrm{~V} / \mathrm{PR}$ films were corrected for baseline variations using DAMO-coated quartz reference slides, prepared as described previously,[47] as blanks. Solution spectra were recorded $v s$. solvent blanks in matched $1.00 \mathrm{~cm}$ or $0.10 \mathrm{~cm}$ path length quartz cuvettes. A VirTis benchtop $\mathrm{K}$ freeze dryer was used to isolate solid $\mathrm{Na}_{4} \mathrm{H}\left[\left(\mathrm{VMo}_{11}\right) \mathrm{O}_{40}\right]$ following its preparation (vide supra). All cyclic voltammetry $(\mathrm{CV})$ measurements were performed using a three-electrode configuration with a model 760 electrochemical workstation (CH Instruments, Austin, TX). The ITO working electrode (coated by the $\mathrm{PMo}_{11} \mathrm{~V} / \mathrm{PR}$ film), $\mathrm{Pt}$ wire counter electrode, and $\mathrm{Ag} / \mathrm{AgCl}$ reference electrode $(\mathrm{CH}$ Instruments) were placed in an electrochemical cell formed from two rectangular Press-to-Seal 
Silicone Isolator gaskets (Grace Bio-Labs, Inc., Bend, OR; catalog no. 664116; $50 \mathrm{~mm} \times 25 \mathrm{~mm}$ $\times 1 \mathrm{~mm}$ ). The gasket contained an array of 10 isolated chamber holes $7 \mathrm{~mm} \times 7 \mathrm{~mm} \times 1 \mathrm{~mm}$ each) and formed a water-tight seal when clamped on the ITO electrode surface,[48] permitting up to 10 separate and independent current measurements per ITO electrode to be made. Each ITO/gasket well was used for an individual measurement by the appropriate chlorate-containing solution to eliminate electrode cross contamination possibilities. Before the chlorate measurement, the multilayers with the corresponding $\mathrm{pH}$ solution were equilibrated by 4 successive CV sweeps from $0.8 \mathrm{~V}$ to $-0.45 \mathrm{~V}$ vs. $\mathrm{Ag} / \mathrm{AgCl}$. Measured currents were corrected for background capacitive contributions at $0.7 \mathrm{~V} v \mathrm{vs}$. $\mathrm{Ag} / \mathrm{AgCl}$ where only non-faradaic processes were observed in the voltammograms. The net currents were averaged from three corrected $\mathrm{CV}$ scans using $\mathrm{E}_{\mathrm{pc}}=-0.4 \mathrm{~V}$ vs. $\mathrm{Ag} / \mathrm{AgCl}$ for the electrocatalytic chlorate reduction wave.

\subsection{LbL Film Depositions}

Quartz slides were cleaned by successive $30 \mathrm{~min}$ immersions in 1:1 v/v $\mathrm{HCl} / \mathrm{CH}_{3} \mathrm{OH}$ and concentrated $\mathrm{H}_{2} \mathrm{SO}_{4}$ with copious water rinsing after each treatment per the literature procedure.[47] For initial experiments, the ITO slides were cleaned by rinsing with water and soaking for 20 min in $\mathrm{H}_{2} \mathrm{SO}_{4}$, followed by copious rinsing with water. Because $\mathrm{H}_{2} \mathrm{SO}_{4}$ slowly removes ITO from the glass surface during the cleaning process, ITO substrates used for the Taguchi and two-level full factorial design experiments for optimization and modeling of electrode performance were cleaned in $\mathrm{H}_{2} \mathrm{SO}_{4}$ for only 10 min to maximize the current response and current response differences among the conditions tested. Cleaned quartz and ITO substrates were immediately coated with PEI film by immersion in the stock PEI solution for $\sim 1 \mathrm{~h}$, followed by triple rinsing with water and drying in a stream of filtered $\mathrm{N}_{2}$ gas. PEI-coated substrates were stored in parafilm ${ }^{\mathrm{TM}}$-sealed capped Coplin jars until needed for experiments. The PEI-coated quartz and ITO substrates were used within 1 week for film deposition.

For LbL deposition of the $\mathrm{PMo}_{11} \mathrm{~V} / \mathrm{PR}$ films, the PEI-coated quartz and ITO substrates were loaded onto a glass carousel, which was then immersed in the stock $2 \mathrm{mg} / \mathrm{mL} \mathrm{PMo}_{11} \mathrm{~V}$ solution (i.e., $1.09 \mathrm{mM}$ ) for $10 \mathrm{~min}$. The substrates were then triple rinsed in water and dried in the stream of filtered $\mathrm{N}_{2}$ gas. Afterwards substrates were immersed in the stock $0.14 \mathrm{mM} \mathrm{PR}$ solution for $10 \mathrm{~min}$, triple rinsed in water, and dried in the filtered $\mathrm{N}_{2}$ gas stream. This sequence was repeated until films bearing the desired number of $\mathrm{PMo}_{11} \mathrm{~V} / \mathrm{PR}$ bilayers, " $\mathrm{n}$ ", of structure Substrate/PEI/(PMo $\left.{ }_{11} \mathrm{~V} / \mathrm{PR}\right)_{\mathrm{n}}$ were deposited. All films having $\mathrm{n} \leq 20$ were deposited without interruption during a single day of work. The samples were stored in parafilm ${ }^{\mathrm{TM}}$-sealed capped Coplin jars for up to 8 weeks until needed for experiments. UV-visible absorbance spectra of the films were periodically recorded as a function of the number of $\mathrm{PMo}_{11} \mathrm{~V} / \mathrm{PR}$ bilayers deposited.

\subsection{Statistically Designed Experiments}

The Taguchi design consisted of an L16 array that examined the importance of the $\mathbf{L}, \mathbf{H}, \mathbf{C}, \mathbf{S}$, and $\mathbf{A}$ variables in 16 total experiments, with each variable assessed at 4 levels as discussed later in the text (vide infra) to determine the conditions for optimum (i.e., maximum current) electrode response. A two-level full factorial design was subsequently employed for the analysis of the effects of the $\mathbf{L}, \mathbf{H}, \mathbf{C}$, and $\mathbf{S}$ variables for electrodes aged $\mathbf{A}=8$ weeks to provide a quantitative model relating current response to the levels of these variables. For each design, experiments 
were performed in random order to minimize the effects of cumulative error. While the twolevel factorial design experiments were completed in $\sim 6 \mathrm{~h}$ during a single day, the Taguchi design required 8 weeks in order to assess the effect of the film age variable, $\mathbf{A}$. During this time the laboratory temperature was maintained at $22 \pm 1{ }^{\circ} \mathrm{C}$ with relative humidity at $45 \pm 5 \%$ and the film-coated electrodes were sealed in Coplin jars to control environmental effects that could introduce additional error into the measurements. Current measurements obtained for the Taguchi design were analyzed by the mean statistical analysis approach [49] to determine the effects of each variable. Corresponding statistically significant effects and residuals for the twolevel full factorial design were determined using the Yates' Algorithm and Reverse Yates' Algorithm, respectively, leading directly to a predictive model of the dependence of the electrode current on the statistically significant $\mathbf{L}, \mathbf{H}, \mathbf{C}$, and $\mathbf{S}$ variables and interactions [50]. All calculations related to the Taguchi and two-level full factorial design experiments were made using author written programs in Microsoft Excel $^{\mathrm{TM}}$.

\subsection{Results and Discussion}

The preparation of bilayer films from $\mathrm{PMo}_{11} \mathrm{~V}$ and PR via the LbL approach on quartz slides and glassy carbon electrodes (GCE) coated by PEI was originally described by Fernandes, et. al. [45] These authors demonstrated monotonic (i.e., nearly linear) film growth as a function of number of bilayers, with overnight interruptions of the deposition process leading to variations in the subsequent growth rate consistent with reorganization of internal structure during film aging. Thicknesses as large as $\sim 150 \mathrm{~nm}$ were observed for films containing 20 bilayers, with measured roughnesses of $\sim 64 \mathrm{~nm}$. Film morphology characteristic of a globular, rather than stratified structure, was also noted consistent with roughness results and electrochemical measurements indicating permeability of the films to ferrocyanide redox probe anions. Reversible one-electron waves in the film CV due to $\mathrm{V}^{\mathrm{V} / \mathrm{IV}}$ at $\mathrm{E}_{\mathrm{pc}}=0.367 \mathrm{~V}$ and $\mathrm{Mo}{ }^{\mathrm{VI} / \mathrm{V}}$ at $0.098 \mathrm{~V},-0.122 \mathrm{~V}$, and -0.266 $\mathrm{V}$ vs. $\mathrm{Ag} / \mathrm{AgCl}$ further confirmed redox activity and accessibility of solution species to the $\mathrm{PMo}_{11} \mathrm{~V}$ component. Film growth was rather insensitive to $\left[\mathrm{PMo}_{11} \mathrm{~V}\right]$ in the $1.0 \mathrm{mM} \leq\left[\mathrm{PMo}_{11} \mathrm{~V}\right]$ $\leq 5.0 \mathrm{mM}$ range for $n<8$ bilayers, though somewhat thinner films were observed using the higher $\left[\mathrm{PMo}_{11} \mathrm{~V}\right]$ in this range when films having $n \geq 8$ bilayers were examined. However, deposition times more strongly influenced film growth, with 10 min treatment times using the $\mathrm{PMo}_{11} \mathrm{~V}$ and PR solutions providing thicker films than 5 min or 20 min treatments.

\subsection{Film Depositions}

Given these favorable characteristics, we fabricated $\mathrm{PMo}_{11} \mathrm{~V} / \mathrm{PR}$ films on PEI-coated quartz and ITO slides for chlorate electrocatalysis studies using $2 \mathrm{mg} / \mathrm{mL}$ (i.e., $1.09 \mathrm{mM}$ ) $\mathrm{PMo}_{11} \mathrm{~V}$ and 0.14 $\mathrm{mM}$ PR solutions in $0.10 \mathrm{M}$ acetate buffer $\mathrm{pH} 4$ with 10 min substrate treatment times corresponding approximately to the optimum deposition conditions identified by Fernandes, et. al [45]. We observed broadened absorbance spectra consistent with previous reports in Figure $1 \mathrm{~A}$ for our films on quartz as functions of the number of PMo ${ }_{11} \mathrm{~V} / \mathrm{PR}$ bilayers, $\mathrm{n}$, for $\mathrm{n}=1-20$. However, our absorbance changes exhibit two linear regions with increasing numbers of $\mathrm{PMo}_{11} \mathrm{~V} / \mathrm{PR}$ bilayers, rather than a single nearly linear growth behavior, as shown in the Figure 1B. In addition, we note that the $535 \mathrm{~nm}$ absorbance of our Quartz/PEI/(PMo $\left.{ }_{11} \mathrm{~V} / \mathrm{PR}\right)_{20}$ film was $\sim 0.38$, which is somewhat smaller than the $\sim 0.46$ value found for the corresponding film in the literature [45]. 
In order to better understand the nature of these differences, we first examined potential effects of the PEI layer on film deposition. We deposited films of structure Quartz/PEI/(PMo $\left.{ }_{11} \mathrm{~V} / \mathrm{PR}\right)_{20}$ on fresh PEI-coated quartz and PEI-coated quartz that had been stored in sealed Coplin jars for up to 1 week at room temperature. Absorbance values at $535 \mathrm{~nm}$ obtained for the films were 0.38 and 0.36 , respectively, indicating that any changes in PEI conformation and degree of protonation or potential PEI reactions involving carbon dioxide [51] or other species present in the ambient atmosphere did not significantly affect film deposition.

We next considered potential effects due to the preparation of the $\mathrm{Na} \mathrm{H}_{4} \mathrm{H}\left[\left(\mathrm{VMo}_{11}\right) \mathrm{O}_{40}\right]$ (i.e., $\left.\mathrm{PVMo}_{11}\right)$ species. Our films were prepared using $\mathrm{Na}_{4} \mathrm{H}\left[\left(\mathrm{VMo}_{11}\right) \mathrm{O}_{40}\right]$ that was freeze dried immediately after preparation, preserving the blue color corresponding to the $\mathrm{V}^{\mathrm{IV}}$ form of the material in the resulting solid.[46] Dissolution of this material in /0.1 M acetate buffer $\mathrm{pH} 4$ (aq) resulted in a blue solution, which was immediately used to deposit the films. The solution color slowly changed to orange-brown, corresponding to the $\mathrm{V}^{\mathrm{V}}$ form of the material, with increasing time at room temperature. Completion of the color change corresponded approximately to the time required to deposit 5-7 $\mathrm{PMo}_{11} \mathrm{~V} / \mathrm{PR}$ bilayer, suggesting that the multi-slope behavior and breakpoint observed in Figure $1 \mathrm{~B}$ were related to the change in oxidation state of the $\mathrm{PMo}_{11} \mathrm{~V}$ species. Because the $\mathrm{V}^{\mathrm{IV}}$ form of the $\mathrm{PMo}_{11} \mathrm{~V}$ possesses an additional unit of negative charge compared to the $\mathrm{V}^{\mathrm{V}}$ form, differences in packing density with $\mathrm{PR}$, film hydration, and inclusion of solution anions such as $\mathrm{OAc}^{-}$are expected to occur during film deposition. These factors in turn will affect film growth rate and absorbance by altering the amounts of $\mathrm{PMo}_{11} \mathrm{~V}$ and $\mathrm{PR}$ deposited. We are unable to separately ascertain the contributions of these factors at this time, but will report the results of our further investigation in a future publication.

\subsection{Chlorate Electrochemistry}

Figure 2A shows a series of cyclic voltammograms for a $\mathrm{n}=6 \mathrm{PVMo}_{11} / \mathrm{PR}$ bilayer film on ITO in aerated $0.10 \mathrm{M}$ sodium acetate $\mathrm{pH} 2.5(\mathrm{aq})$ solution as a function of scan rate, together with a plot of the scan rate dependence of the current at $\mathrm{E}_{\mathrm{pc}}=-0.250 \mathrm{~V}$ and $\mathrm{E}_{\mathrm{pa}}=-0.203 \mathrm{~V}$. Cathodic and anodic peak currents vary linearly with scan rate in Figure $2 \mathrm{~B}$, as expected for surface confined processes.[52] The individual peaks observed in the $-0.45 \leq \mathrm{E} \leq 0.80 \mathrm{~V}$ potential range scanned are attributed to the polyoxometalate, with noticeable differences to the literature values[45] most likely do to different conditions e.g., ITO vs. GCE, $\mathrm{pH} \sim 2.5$ / $0.10 \mathrm{M}$ sodium acetate electrolyte vs. $0.10 \mathrm{M}$ sodium acetate (aq) buffer $\mathrm{pH} 4$ electrolyte, PR-terminated vs. $\mathrm{PVMo}_{11}$-terminated films, reference electrode conditions, and effective temperature at the time of measurement in experiments carried out in different laboratories in different countries.

The peak positions and assignments from the cyclic voltammograms are listed in Table 1 . The cathodic peak potential $\left(\mathrm{E}_{\mathrm{pc}}\right)$ of Peak 1 has shifted from $\mathrm{E}_{\mathrm{pc}}=0.290$ to $0.323 \mathrm{~V}$ compared to the literature. Peak 2 has split from a broad peak with $\mathrm{E}_{\mathrm{pc}}=0.098 \mathrm{~V}$ to two peaks with $\mathrm{E}_{\mathrm{pc}}=0.035$ and $-0.068 \mathrm{~V}$. Peak 3 has shifted from $\mathrm{E}_{\mathrm{pc}}=-0.122$ to $-0.250 \mathrm{~V}$, and Peak 4 has shifted from $\mathrm{E}_{\mathrm{pc}}=-0.266$ to $\mathrm{E}_{\mathrm{pc}}=-0.44 \mathrm{~V}$. 
Table 1. Electrochemical parameters for $\mathrm{n}=6 \mathrm{PVMo}_{11} / \mathrm{PR}$ bilayer film

\begin{tabular}{cccc|cc}
\hline \multicolumn{4}{c|}{ This work $^{\mathrm{a}}$} & \multicolumn{2}{c}{ Literature $^{\mathrm{b}}$} \\
\hline Peak & $\mathrm{E}_{\mathrm{pc}}$ & $\mathrm{E}_{\mathrm{pa}}$ & $\left(\Delta \mathrm{E}_{\mathrm{p}}\right)$ & $\mathrm{E}_{\mathrm{pc}}$ & $\left(\Delta \mathrm{E}_{\mathrm{p}}\right)$ \\
\hline 1 & 0.290 & $0.355^{\mathrm{c}}$ & 0.065 & 0.367 & 0.06 \\
$2 \mathrm{a}$ & 0.025 & 0.045 & 0.020 & 0.098 & $0.029-0.09$ \\
$2 \mathrm{~b}$ & -0.080 & -0.055 & 0.025 & - & - \\
3 & -0.250 & -0.203 & 0.047 & -0.122 & $0.029-0.09$ \\
4 & -0.400 & -0.360 & 0.040 & -0.266 & $0.029-0.09$ \\
\hline
\end{tabular}

${ }^{\mathrm{a}} \mathrm{Scan}$ rate $=100 \mathrm{mV} \cdot \mathrm{s}^{-1}$

${ }^{\mathrm{b}}$ Reference [45]

${ }^{c}$ Shoulder at $0.53 \mathrm{~V}$ vs. $\mathrm{Ag} / \mathrm{AgCl}$

No redox processes are observed for the PR species. Peak-to-peak separations $\left(\Delta \mathrm{E}_{\mathrm{p}}\right)$ of $\sim 0.06 \mathrm{~V}$ are observed for the V-based wave assigned to Peak 1, whereas $\Delta \mathrm{E}_{\mathrm{p}}$ values between 0.02 to 0.05 $\mathrm{V}$ are noted for Mo-based waves assigned for Peaks 2 thru 4. Integration of the cathodic and anodic waves of Peak 1 yielded a polyoxometalate surface coverage of $\Gamma=0.16 \pm 0.05$ nmole $\cdot \mathrm{cm}^{-2}$ for a film comprising $\mathrm{n}=6$ bilayers.

We note in Figure 2A that redox processes associated only with the $\mathrm{PVMo}_{11}$ component of the film are observed, even though the $\mathrm{CV}$ was carried out using aerated electrolyte solutions. Likewise, the addition of TNT at trace levels $\left(0.01 \mathrm{mg} \cdot \mathrm{mL}^{-1}\right)$ provides no additional signals (Figure S1A, Supporting Material), consistent with the selective nature of the modified electrode.

Figure $3 \mathrm{~A}$ illustrates the effect of the presence of chlorate in the solution on the $\mathrm{CV}$ of the 1 week old $n=6 \mathrm{PVMo}_{11} / \mathrm{PR}$ bilayer film on ITO. A strong catalytic wave is observed at the $\mathrm{E}_{\mathrm{pc} 4}$ Mo-based wave, corresponding to the $\mathrm{pH}$ dependent catalyzed reduction of chlorate to chloride according to eq. (1) and (2):

$$
\begin{aligned}
& \mathrm{PV}^{\mathrm{IV}} \mathrm{Mo}_{4}{ }^{\mathrm{V}} \mathrm{Mo}_{7}{ }^{\mathrm{VI}} \mathrm{O}_{40}{ }^{10-}+2 \mathrm{e}^{-} \rightarrow \mathrm{PV}^{\mathrm{IV}} \mathrm{Mo}_{6}{ }^{\mathrm{V}} \mathrm{Mo}_{5}{ }^{\mathrm{VI}} \mathrm{O}_{40}{ }^{12-}\left(\mathrm{E}_{\mathrm{pc} 4}=-0.40 \mathrm{~V} v s . \mathrm{Ag} / \mathrm{AgCl}\right) \\
& 3 \mathrm{PV}^{\mathrm{IV}} \mathrm{Mo}_{6}{ }^{\mathrm{V}} \mathrm{Mo}_{5}{ }^{\mathrm{VI}} \mathrm{O}_{40}{ }^{12-}+\mathrm{ClO}_{3}{ }^{-}+6 \mathrm{H}^{+} \rightarrow 3 \mathrm{PV}^{\mathrm{IV}} \mathrm{Mo}_{4}{ }^{\mathrm{V}} \mathrm{Mo}_{7}{ }^{\mathrm{VI}} \mathrm{O}_{40}{ }^{10-}+3 \mathrm{H}_{2} \mathrm{O}+\mathrm{Cl}^{-} \\
& 3 \mathrm{PV}^{\mathrm{IV}} \mathrm{Mo}_{6}{ }^{\mathrm{V}} \mathrm{Mo}_{5}{ }^{\mathrm{VI}} \mathrm{O}_{40}{ }^{12-}+\mathrm{ClO}_{3}{ }^{-}+3 \mathrm{H}_{2} \mathrm{O} \rightarrow 3 \mathrm{PV}^{\mathrm{IV}} \mathrm{Mo}_{4}{ }^{{ }} \mathrm{Mo}_{7}{ }^{\mathrm{VI}} \mathrm{O}_{40}{ }^{10-}+6 \mathrm{OH}^{-}+\mathrm{Cl}^{-}
\end{aligned}
$$

Two one-electron reductions of $\mathrm{Mo}^{\mathrm{VI}}$ components of the $\mathrm{PVMo}_{11}$ species in the film to the $\mathrm{Mo}^{\mathrm{V}}$ oxidation state produce a highly reduced product in eq. (1) capable of reducing chlorate to chloride under acid or basic conditions in eqs. (2). The oxidized $\mathrm{PV}^{\mathrm{IV}} \mathrm{Mo}_{4}{ }^{\mathrm{V}} \mathrm{Mo}_{7}{ }^{\mathrm{VI}} \mathrm{O}_{40}{ }^{10-}$ species produced as the product in eqs. (2) is identically the same species serving as reactant in eq. (1). At the applied electrode potential designated by $\mathrm{E}_{\mathrm{pc} 4}$, it is immediately reduced once again to $\mathrm{PV}^{\mathrm{IV}} \mathrm{Mo}_{6}{ }^{\mathrm{V}} \mathrm{Mo}_{5}{ }^{\mathrm{VI}} \mathrm{O}_{40}{ }^{12-}$ and reacts with additional chlorate to continue the catalytic cycle.

Catalytic reduction current increased with $\left[\mathrm{ClO}_{3}{ }^{-}\right]$in solution in Figure $3 \mathrm{~A}$, resulting in a linear calibration curve in Figure 3B. We calculated the limit of detection (LOD) using the equation LOD $=3 \sigma / \mathrm{m}$ where " $\sigma$ " is the standard deviation of signal at the lowest concentration tested and " $m$ " is the slope of the calibration curve [53]. From Figure 3B, The LOD $=220 \mu \mathrm{M}$ and the 
sensitivity $=0.022 \pm 0.002 \mu \mathrm{A} / \mu \mathrm{M}$ of $\mathrm{KClO}_{3}$. In small volume electrochemical cell of $100 \mu \mathrm{L}$, this would correspond to $2.6 \mu \mathrm{g}$ of $\mathrm{KClO}_{3}$, which is sufficient to provide a "yes/no" answer for detection of bulk chlorate salts in the field for surveillance of bomb making activities.

\subsection{Electrode Performance Optimization}

Having completed the initial characterization of our electrodes and demonstrated their ability to catalyze electroreduction of chlorate, we proceeded to determine conditions for optimum performance using a Taguchi L16 array. The factors (i.e., variables) examined included number of $\mathrm{PMo}_{11} \mathrm{~V} / \mathrm{PR}$ bilayers present on the electrode $(\mathbf{L})$, solution acidity/pH $(\mathbf{H})$, solution $\left[\mathrm{ClO}_{3}{ }^{-}\right]$ $(\mathbf{C} ; \mu \mathrm{M}), \mathrm{CV}$ scan rate $\left(\mathbf{S} ; \mathrm{mV} \cdot \mathrm{s}^{-1}\right)$, and $\mathrm{PMo}_{11} \mathrm{~V} / \mathrm{PR}$ film age $(\mathbf{A}$; weeks). Each factor was examined at $\mathrm{k}=4$ levels at the following factor/level values as follows: $\mathbf{L} / 1=3, \mathbf{L} / 2=4, \mathbf{L} / 3=$ 5, and $\mathbf{L} / 4=6 \mathrm{PMo}_{11} \mathrm{~V} / \mathrm{PR}$ bilayers; $\mathbf{H} / 1=1.32 \pm 0.02, \mathbf{H} / 2=1.80 \pm 0.01, \mathbf{H} / 3=2.31 \pm 0.01$, and $\mathbf{H} / 4=2.85 \pm 0.03 \mathrm{pH}$ units; $\mathbf{C} / 1=250, \mathbf{C} / 2=500, \mathbf{C} / 3=750$, and $\mathbf{C} 4=1000 \mu \mathrm{M}$ chlorate; $\mathbf{S} / 1=50, \mathbf{S} / 2=100, \mathbf{S} / 3=150$, and $\mathbf{S} / 4=200 \mathrm{mV} \cdot \mathrm{s}^{-1}$ scan rate; $\mathbf{A} / 1=1, \mathbf{A} / 2=2, \mathbf{A} / 3=5$, and $\mathbf{A} / 4=8$ weeks aging.

Table 2 summarizes the Taguchi L16 array, with each row indicating an experiment at conditions corresponding to the coded values for each factor shown. Net currents obtained for each of $\mathrm{x}=3$ replicates after corrections for capacitive effects are shown, together with the average current and its standard deviation for each of $\mathrm{m}=16$ total experiments. The $\mathrm{S} / \mathrm{N}$ ratio is defined for optimization related to current maximization by summing the inverse squares of each net current measurement, dividing by the number of replicate measurements, " $x=3$ ", taking the base 10 logarithm of the value obtained, and finally multiplying that value by -10 . 
Table 2. Taguchi L16 Array

\begin{tabular}{|c|c|c|c|c|c|c|c|c|c|c|c|}
\hline \multirow{2}{*}{$\begin{array}{l}\text { Expt. } \\
\text { No. }\end{array}$} & \multicolumn{5}{|c|}{ Variables } & \multicolumn{3}{|c|}{ Net Current, $i(\mu \mathrm{A})$} & \multirow{2}{*}{$\begin{array}{l}\text { Average } \\
i_{\text {ave }}(\mu \mathrm{A})\end{array}$} & \multirow{2}{*}{$\begin{array}{c}\text { Standard } \\
\text { Deviation }(\sigma)\end{array}$} & \multirow{2}{*}{$\begin{array}{c}\text { S/N } \\
\text { Ratio }\end{array}$} \\
\hline & $\mathbf{L}$ & $\mathbf{H}$ & $\mathbf{C}$ & $\mathbf{S}$ & $\mathbf{A}$ & $i_{1}$ & $i_{2}$ & $i_{3}$ & & & \\
\hline 1 & 1 & 1 & 1 & 1 & 1 & 8.69 & 6.89 & 6.06 & 7.21 & 0.87 & 16.88 \\
\hline 2 & 1 & 2 & 2 & 2 & 2 & 17.49 & 14.77 & 13.57 & 15.28 & 1.31 & 23.54 \\
\hline 3 & 1 & 3 & 3 & 3 & 3 & 16.62 & 15.47 & 14.98 & 15.69 & 0.55 & 23.89 \\
\hline 4 & 1 & 4 & 4 & 4 & 4 & 49.26 & 40.56 & 37.20 & 42.34 & 4.12 & 32.36 \\
\hline 5 & 2 & 1 & 2 & 3 & 4 & 41.65 & 34.86 & 33.58 & 36.70 & 3.05 & 31.18 \\
\hline 6 & 2 & 2 & 1 & 4 & 3 & 43.12 & 32.82 & 29.96 & 35.30 & 4.74 & 30.65 \\
\hline 7 & 2 & 3 & 4 & 1 & 2 & 18.94 & 15.75 & 14.18 & 16.29 & 1.56 & 24.05 \\
\hline 8 & 2 & 4 & 3 & 2 & 1 & 42.59 & 36.58 & 33.70 & 37.62 & 2.93 & 31.39 \\
\hline 9 & 3 & 1 & 3 & 4 & 2 & 84.37 & 72.68 & 70.22 & 75.76 & 5.28 & 37.51 \\
\hline 10 & 3 & 2 & 4 & 3 & 1 & 121.39 & 110.27 & 104.17 & 111.95 & 5.54 & 40.93 \\
\hline 11 & 3 & 3 & 1 & 2 & 4 & 30.97 & 25.42 & 23.06 & 26.48 & 2.66 & 28.27 \\
\hline 12 & 3 & 4 & 2 & 1 & 3 & 22.44 & 19.34 & 17.62 & 19.80 & 1.55 & 25.81 \\
\hline 13 & 4 & 1 & 4 & 2 & 3 & 39.05 & 28.03 & 24.22 & 30.43 & 5.16 & 29.17 \\
\hline 14 & 4 & 2 & 3 & 1 & 4 & 14.93 & 12.46 & 11.43 & 12.94 & 1.18 & 22.08 \\
\hline 15 & 4 & 3 & 2 & 4 & 1 & 100.70 & 81.71 & 73.93 & 85.45 & 9.07 & 38.42 \\
\hline 16 & 4 & 4 & 1 & 3 & 2 & 82.25 & 68.55 & 62.32 & 71.04 & 6.63 & 36.86 \\
\hline
\end{tabular}

The mean $\mathrm{S} / \mathrm{N}$ ratio of each factor, $\mathbf{F}$, defined at each level, "i", of that factor is given by $\mathrm{M}_{\mathrm{i}}{ }^{\mathrm{F}}$. The $\mathrm{M}_{\mathrm{i}}{ }^{\mathrm{F}}$ are calculated by summing the four $\mathrm{S} / \mathrm{N}$ values corresponding to a given fixed level for that factor and dividing by $\mathrm{k}=4$ (i.e., the number of levels available for each factor). For example, factor $\mathbf{A}$ at level 2 (i.e., $\mathbf{A} / 2$ ) occurs in experiments 2, 7, 9, and 16, corresponding to $\mathrm{S} / \mathrm{N}$ ratios of $23.54,24.04,37.51$, and 36.86 in Table 2. These values are shown in the array in Table 3 as entries in columns $\mathrm{j}=1-4$ in the $\mathbf{A} / 2$ row. Their sum is 121.96 , which when divided by $\mathrm{k}=4$ levels for each variable yields the $\mathrm{M}_{\mathrm{i}}^{\mathrm{F}}=\mathrm{M}_{2}{ }^{\mathrm{A}}=30.49$ value shown in Table 3 . Population of the remaining $\mathrm{M}_{\mathrm{i}}^{\mathrm{F}}$ in analogous fashion completes Table 3. 
Table 3. Mean S/N Ratios for Each Factor

\begin{tabular}{|c|c|c|c|c|c|c|}
\hline \multirow[b]{2}{*}{ Factor/Level } & \multicolumn{5}{|c|}{$\left[(\mathbf{S} / \mathbf{N})_{i}{ }^{\mathrm{F}}\right]_{\mathbf{j}}$} & \multirow{2}{*}{$\begin{array}{c}\text { Experimental } \\
\text { Conditions }\end{array}$} \\
\hline & $\mathrm{j}=1$ & $\mathbf{j}=\mathbf{2}$ & $\mathbf{j}=\mathbf{3}$ & $j=4$ & $\mathbf{M}_{\mathbf{i}}^{\mathbf{F}}$ & \\
\hline $\mathrm{L} / 1$ & 16.88 & 23.54 & 23.89 & 32.36 & 24.17 & $\mathbf{L} / 1=3$ bilayers \\
\hline$L / 2$ & 31.18 & 30.65 & 24.05 & 31.39 & 29.32 & $\mathbf{L} / 2=4$ bilayers \\
\hline$L / 3$ & 37.51 & 40.93 & 28.27 & 25.81 & 33.13 & $L / 3=5$ bilayers \\
\hline $\mathbf{L} / 4$ & 29.17 & 22.08 & 38.42 & 36.86 & 31.63 & $\mathbf{L} / 4=6$ bilayers \\
\hline H/1 & 16.88 & 31.18 & 37.51 & 29.17 & 28.68 & $\mathbf{H} / 1=1.32 \pm 0.02 \mathrm{pH}$ \\
\hline$H / 2$ & 23.54 & 30.65 & 40.93 & 22.08 & 29.30 & $\mathbf{H} / 2=1.80 \pm 0.01 \mathrm{pH}$ \\
\hline H/3 & 23.89 & 24.05 & 28.27 & 38.42 & 28.66 & $\mathbf{H} / 3=2.31 \pm 0.01 \mathrm{pH}$ \\
\hline$H / 4$ & 32.36 & 31.39 & 25.81 & 36.86 & 31.60 & $H / 4=2.85 \pm 0.03 p H$ \\
\hline $\mathrm{C} / 1$ & 16.88 & 30.65 & 28.27 & 36.86 & 28.17 & $\mathrm{C} / 1=250 \mu \mathrm{M} \mathrm{ClO}_{3}^{-}$ \\
\hline $\mathrm{C} / 2$ & 23.54 & 31.18 & 25.81 & 38.42 & 29.74 & $\mathbf{C} / 2=500 \mu \mathrm{M} \mathrm{ClO}_{3}^{-}$ \\
\hline $\mathrm{C} / 3$ & 23.89 & 31.39 & 37.51 & 22.08 & 28.72 & $\mathrm{C} / 3=750 \mu \mathrm{M} \mathrm{ClO}_{3}^{-}$ \\
\hline$C / 4$ & 32.36 & 24.05 & 40.93 & 29.17 & 31.63 & $\mathrm{C} / 4=1000 \mu \mathrm{MClO}$ \\
\hline $\mathbf{S} / 1$ & 16.88 & 24.05 & 25.81 & 22.08 & 22.20 & $\mathrm{~S} / 1=50 \mathrm{mV} \cdot \mathrm{s}^{-1}$ \\
\hline $\mathbf{S} / 2$ & 23.54 & 31.39 & 28.27 & 29.17 & 28.09 & $\mathbf{S} / 2=100 \mathrm{mV} \cdot \mathrm{s}^{-1}$ \\
\hline $\mathbf{S} / 3$ & 23.89 & 31.18 & 40.93 & 36.86 & 33.21 & $\mathrm{~S} / 3=150 \mathrm{mV} \cdot \mathrm{s}^{-1}$ \\
\hline$S / 4$ & 32.36 & 30.65 & 37.51 & 38.42 & 34.74 & $S / 4=200 \mathrm{mV}^{-1}$ \\
\hline$A / 1$ & 16.88 & 31.39 & 40.93 & 38.42 & 31.90 & $A / 1=1$ week aged \\
\hline $\mathbf{A} / 2$ & 23.54 & 24.05 & 37.51 & 36.86 & 30.49 & $\mathbf{A} / 2=2$ weeks aged \\
\hline $\mathbf{A} / 3$ & 23.89 & 30.65 & 25.81 & 29.17 & 27.38 & $\mathbf{A} / 3=5$ weeks aged \\
\hline $\mathbf{A} / 4$ & 32.36 & 31.18 & 28.27 & 22.08 & 28.47 & $\mathbf{A} / 4=8$ weeks aged \\
\hline
\end{tabular}

Conditions associated with the maximum current response for the electrode corresponded to the levels of each factor having the largest $\mathrm{M}_{\mathrm{i}}^{\mathrm{F}}$ value. In this case, the maximum current response corresponded to the $\mathbf{L} / 3, \mathbf{H} / 4, \mathbf{C} / 4, \mathbf{S} / 4, \mathbf{A} / 1$ factor level combination indicated in bold italic text in Table 3. That is, an electrode comprising $\mathbf{L}=5$ bilayers aged $\mathbf{A}=1$ week in a solution containing $\mathbf{C}=1000 \mu \mathrm{M}$ chlorate at $\mathbf{H}=2.85 \mathrm{pH}$ scanned at $\mathbf{S}=200 \mathrm{mV} \cdot \mathrm{s}^{-1}$ provides the largest current response. Analysis of variance calculations (ANOVA, note Section II, Supplementary Material) using the measured net current values in Table 2 identified scan rate, $\mathbf{S}$, as the factor most contributing to the current response, followed in decreasing order by the variables $\mathbf{L}, \mathbf{A}, \mathbf{C}$, and $\mathbf{H}$.

Further examination of the $\mathrm{M}_{\mathrm{i}}^{\mathrm{F}}$ values and their variations among the levels studied for each factor provide additional insight into the nature of the electrode and the chlorate electroreduction process. For example, Table 3 identified a film having $\mathbf{L} / 3=5$ bilayers as the most efficient in promoting maximum current response. The thinner 3 and 4 bilayer films and the thicker 6 bilayer film provided lower responses, as indicated by their $\mathrm{M}_{\mathrm{i}}^{\mathrm{L}}$ values. We ascribe the proportional current reductions noted for the 3 and 4 bilayer films to the presence of less redox active $\mathrm{PMo}_{11} \mathrm{~V}$ in these thinner films. In contrast, the 6 bilayer film contained the most $\mathrm{PMo}_{11} \mathrm{~V}$ yet also exhibited decreased current compared to the 5 bilayer film. We note that our 6 bilayer film corresponds approximately to the absorbance break point in Figure 1B, at which differences in film packing ostensibly occur as oxidation of the blue $\mathrm{V}^{\mathrm{IV}}$ form of the $\mathrm{PMo}_{11} \mathrm{~V}$ solution species deposited to the orange $\mathrm{V}^{\mathrm{V}}$ form (vide supra) is completed. Associated changes in 
packing density and internal film structure, together with increased separation between the underlying electrode and solution as film thickness increases, resulting in lowered film permeability and currents provide an explanation for our observations consistent with similar behavior noted for corresponding thick $\left(\mathrm{PR} / \mathrm{PMo}_{11} \mathrm{~V}\right)_{\mathrm{n}}$ films $(\mathrm{n} \geq 5)$ elsewhere [45].

Not surprisingly, film aging also significantly affects the current response. The largest $\mathrm{M}_{\mathrm{i}}{ }^{\mathrm{A}}$ in Table 3 was observed using the films aged 1 week. Thereafter, current response fell until the film has aged 5 weeks, then recovered slightly $(\sim 10 \%)$ for the 8 week old film. This behavior indicates some restructuring of the films as they age, leading to changes in permeability and mechanical properties reflected in the current response. Similar behaviors have been noted for paraquat-silicate [54-56] and polyelectrolyte multilayer [57-60] films, in which components are usually deposited in kinetically trapped conformations that slowly relax via chemical or physical processes, respectively, to their thermodynamically stable equilibrium conformations as the films age. That similar phenomena related to changes in internal structure occur in our films is also supported by observations of slight changes in film absorbance noted by Fernandes, et. al. [16] in analogous $\left(\mathrm{PR} / \mathrm{PMo}_{11} \mathrm{~V}\right)_{\mathrm{n}}$ films following overnight drying/re-wetting cycles during film deposition.

The $\mathrm{pH}$ dependence in Table 3 indicates that current is generally enhanced by increasing the solution $\mathrm{pH}$, although the changes in $\mathrm{M}_{\mathrm{i}}^{\mathrm{H}}$ are non-monotonic suggesting that factor $\mathbf{H}$ may be strongly influenced by one or more other factors in our system. Nevertheless, the $\mathbf{H} / 4=2.85 \mathrm{pH}$ solution provided the largest response. This contrasts with behaviors noted for chlorate electroreduction by other polyoxometalates [21, 61, 62] for which reduction is generally more favorable at lower $\mathrm{pH}$. Chlorate electroreduction can occur in both acidic and basic solutions [6, 40] with reduction in acidic solution thermodynamically much more favorable:

$$
\begin{aligned}
& \mathrm{ClO}_{3}{ }^{-}+6 \mathrm{H}^{+}+6 \mathrm{e}^{-} \leftrightarrow \mathrm{Cl}^{-}+3 \mathrm{H}_{2} \mathrm{O} \quad\left(\mathrm{E}^{0}=1.45 \mathrm{~V} \text { vs. S.H.E.; acidic } \mathrm{pH}\right) \\
& \mathrm{ClO}_{3}{ }^{-}+3 \mathrm{H}_{2} \mathrm{O}+6 \mathrm{e}^{-} \leftrightarrow \mathrm{Cl}^{-}+6 \mathrm{OH}^{-} \quad\left(\mathrm{E}^{0}=0.62 \mathrm{~V} \text { vs. S.H.E.; basic } \mathrm{pH}\right)
\end{aligned}
$$

The fact that chlorate electroreduction for our films was somewhat more favorable at higher $\mathrm{pH}$ suggests that reduction may occur primarily via eq. (4), rather than eq. (3). Chlorate reduction via eq. (4) is supported by the structure of our films, which are terminated by a layer of cationic, hydrophobic PR species also contained within the film interior. The PR component was expected to provide an electrostatic and hydrophobic barrier inhibiting entry of protons, which possess a high charge density and highly structured water solvent shell, into the film. In contrast, for a neutral molecule such as water or poorly solvated chaotropic anions such as $\mathrm{ClO}_{3}{ }^{-} \mathrm{or} \mathrm{Cl}^{-}$, which possess zero or favorable (i.e., anionic) lower charge densities, respectively, entry required to complete the electroreduction is more facile [63].

The $\mathbf{S}$ and $\mathbf{C}$ factors changes in current response are generally consistent with expectations for $\mathrm{CV}$ measurements. For example, CV currents increased with scan rate, $\mathbf{S}$, which reflects the change in driving force for the reaction at the electrode. $\mathrm{M}_{\mathrm{i}}{ }^{\mathrm{S}}$ values in Table 3 increased in a monotonic fashion with $\mathbf{S}$ as expected, with maximum current observed for the fastest scan rate, $\mathbf{S} / 4$. In similar manner, the largest current response occurred at the highest chlorate concentration $(\mathbf{C} / 4=1000 \mu \mathrm{M})$, consistent with the current $v s .\left[\mathrm{ClO}_{3}{ }^{-}\right]$response already noted in 
Figure 3B. The non-monotonic change in $\mathrm{M}_{\mathrm{i}}{ }^{\mathrm{C}}$ on proceeding from level $\mathrm{i}=1$ to $\mathrm{i}=4$, however, is analogous to that observed for $\mathrm{pH}$ with $\mathrm{M}_{\mathrm{i}}^{\mathrm{H}}$, again suggesting that one or more other factors, such as film age, may interact with and alter the chlorate concentration effect. These nonmonotonic variations in $\mathrm{M}_{\mathrm{i}}^{\mathrm{C}}$ and $\mathrm{M}_{\mathrm{i}}^{\mathrm{H}}$ are discussed below.

\subsection{Electrode Performance Model}

In conjunction with the Taguchi study, experiments were also conducted using a two-level full factorial design to obtain a mathematical model for the system. Given the age effect results noted for our films from the Taguchi analysis we restricted our study to films aged 8 weeks, at which time the films had reached structural equilibrium (note Figure S1B). Therefore our design probed only the effects of the factors, $\mathbf{L}, \mathbf{H}, \mathbf{C}$, and $\mathbf{S}$, each examined at two levels using coded levels (i.e., \pm 1 ) for each factor as defined by eq. (5):

$p=2(q-a) /(b-a)-1$

In eq. (5), $a$ and $b$ represent the low and high values for a given factor associated with its -1 and +1 coded values in the design; $q$ is any intermediate value for the factor within the range $a \leq q \leq$ $b$; and $p$ is its corresponding value linearly mapped onto the $-1 \leq p \leq+1$ range. We chose value of $\mathbf{L}=-1 \equiv 3$ bilayers and $\mathbf{L}=+1 \equiv 5$ bilayers to further investigate the region of monotonic increase in current with increased bilayer number identified by the Taguchi design. For the solution $\mathrm{pH}$ factor, we defined $\mathbf{H}$ directly in terms of $\left[\mathrm{H}^{+}\right]$in solution, rather than the $\mathrm{pH}$ values associated with each solution, with $\mathbf{H}=-1 \equiv 0.0014 \mathrm{M} \mathrm{HCl}$ (i.e., $\mathrm{pH} 2.85$ ) and $\mathbf{H}=+1 \equiv 0.0479$ $\mathrm{M} \mathrm{HCl}$ (i.e., $\mathrm{pH}$ 1.32). For the remaining factors, coded levels corresponded to the minimum and maximum values of each factor used in the Taguchi design as follows: $\mathbf{C}=-1 \equiv 250 \mu \mathrm{M} \mathrm{ClO}_{3}{ }^{-}$ and $\mathbf{C}=+1 \equiv 1000 \mu \mathrm{M} \mathrm{ClO}_{3}{ }^{-}$; and $\mathbf{S}=-1 \equiv 50 \mathrm{mV} \cdot \mathrm{s}^{-1}$ and $\mathbf{S}=+1 \equiv 200 \mathrm{mV} \cdot \mathrm{s}^{-1}$. A standard order design matrix of the $2^{4}=16$ possible combinations of factor levels was prepared as shown in Table 4. Effects were calculated from averages of three corrected net current measurements for each experiment and the probability of each effect occurring solely due to random error was computed using eq. (6):

$P_{j}=100(j-1 / 2) / 15 \quad(j=1-15$ Effects $)$

In eq. (6), $\mathrm{P}_{\mathrm{j}}$ is the probability that the $\mathrm{j}^{\text {th }}$ Effect is statistically non-significant and occurs simply due to random error. 
Table 4: Two-level Full Factorial Design Effects and Probabilities Due to Random Error

\begin{tabular}{|c|c|c|c|c|c|c|c|c|c|}
\hline \multirow{2}{*}{$\begin{array}{l}\text { Expt. } \\
\text { No. }\end{array}$} & \multicolumn{4}{|c|}{ Factors $(F)^{\mathbf{a}}$} & \multirow{2}{*}{$\begin{array}{c}\text { Average } \\
\text { Current, } i_{\text {ave }}(\mu \mathrm{A})^{b}\end{array}$} & \multirow{2}{*}{$\begin{array}{c}\text { Effect } \\
\text { ID }^{c}\end{array}$} & \multirow{2}{*}{$\begin{array}{c}\text { Effect } \\
(E)^{d}\end{array}$} & \multirow{2}{*}{$\begin{array}{c}\text { Probability } \\
\left(\mathbf{P}_{\mathbf{j}}\right)^{\mathbf{e}}\end{array}$} & \multirow{2}{*}{$\begin{array}{l}\text { Order } \\
(\mathbf{j})^{\text {f }}\end{array}$} \\
\hline & $\mathbf{L}$ & $\mathbf{H}$ & $\mathbf{C}$ & $\mathbf{S}$ & & & & & \\
\hline 1 & -1 & -1 & -1 & -1 & 11.14 & Average & 29.32 & --- & --- \\
\hline 2 & +1 & -1 & -1 & -1 & 17.66 & $\mathrm{~L}$ & 13.15 & 90.000 & 14 \\
\hline 3 & -1 & +1 & -1 & -1 & 6.98 & $\mathrm{H}$ & -11.93 & 3.333 & 1 \\
\hline 4 & +1 & +1 & -1 & -1 & 10.31 & $\mathrm{LH}$ & -1.36 & 16.667 & 3 \\
\hline 5 & -1 & -1 & +1 & -1 & 13.74 & $\mathrm{C}$ & 6.91 & 83.333 & 13 \\
\hline 6 & +1 & -1 & +1 & -1 & 21.80 & $\mathrm{LC}$ & 2.58 & 70.000 & 11 \\
\hline 7 & -1 & +1 & +1 & -1 & 10.21 & $\mathrm{HC}$ & 2.29 & 63.333 & 10 \\
\hline 8 & +1 & +1 & +1 & -1 & 21.03 & LHC & 0.75 & 50.000 & 8 \\
\hline 9 & -1 & -1 & -1 & +1 & 42.13 & $\mathrm{~S}$ & 30.42 & 96.667 & 15 \\
\hline 10 & +1 & -1 & -1 & +1 & 60.98 & LS & 5.97 & 76.667 & 12 \\
\hline 11 & -1 & +1 & -1 & +1 & 22.08 & $\mathrm{HS}$ & -7.98 & 10.000 & 2 \\
\hline 12 & +1 & +1 & -1 & +1 & 35.65 & LHS & -1.26 & 23.333 & 4 \\
\hline 13 & -1 & -1 & +1 & +1 & 45.11 & $\mathrm{CS}$ & 1.74 & 56.667 & 9 \\
\hline 14 & +1 & -1 & +1 & +1 & 69.74 & LCS & 0.32 & 36.667 & 6 \\
\hline 15 & -1 & +1 & +1 & +1 & 30.57 & HCS & 0.49 & 43.333 & 7 \\
\hline 16 & +1 & +1 & +1 & +1 & 50.01 & LHCS & -0.73 & 30.000 & 5 \\
\hline
\end{tabular}

${ }^{\mathrm{a}}$ Coded factor levels defined in eq. (5). Note also Section III, Supplementary Material.

${ }^{\mathrm{b}}$ Average of 3 net current measurements (note Table S-6, Supplementary Material).

${ }^{c}$ Identification of factors and/or factor interactions associated with calculated Effects.

'Effects calculated using the Yates' Algorithm (note Table S-7, Supplementary Material).

${ }^{\mathrm{e}}$ Probability of the Effect being due solely to random error calculated using eq. (6).

${ }^{\mathrm{f}}$ Numerical order of the Effects from most negative to most positive for probability of random occurrence assignment, $\mathrm{P}_{\mathrm{j}}$, using eq. (6).

The normal probability plot of the Effects $v s . \mathrm{P}_{\mathrm{j}}$ is shown in Figure 4. Nine points comprise the straight line section of the plot, signifying Effects that are statistically non-significant and can be attributed to random error. The remaining 6 points deviating from the straight line portion of the plot represent Effects that provide statistically significant contributions to the observed current response. These comprise the Effects due to the $\mathbf{L}, \mathbf{S}, \mathbf{H}$, and $\mathbf{C}$ factors and the $\mathbf{H S}$ and $\mathbf{L S}$ factor interactions. ANOVA calculations (note Section IV, Supplementary Material) confirm that these factors and factor interactions are significant at the 0.999 confidence level.

The results of the two-level full factorial study are generally consistent with those of the Taguchi design. The largest Effects are those due to the $\mathbf{S}$ (i.e., 30.42) and $\mathbf{L}$ (i.e., 13.15) factors, which provide positive contributions to the observed current as their values increase within the range of values studied. The contribution of the $\mathbf{H}$ factor (i.e., -11.93) is negative, [64] with increasing acidity (i.e., lower $\mathrm{pH}$ ) diminishing the current. These Effects are augmented by smaller (relative to the $\mathbf{S}$ and $\mathbf{L}$ Effects) antagonistic HS (i.e., -7.98) and synergistic LS (i.e., 5.97) interactions that further alter current response in the system.

We note that the relative contribution of the $\mathbf{H}$ (i.e., -11.93) factor exceeds that of the $\mathbf{C}$ (i.e., 6.91) factor in Table 4, in opposition to the ANOVA results from the Taguchi design. However, 
the Taguchi design includes the film age factor, $\mathbf{A}$, whereas film age was not examined in the two-level full factorial design. This behavior suggests that current contributions from factors $\mathbf{C}$ and/or $\mathbf{H}$ are affected by film age. Factor $\mathbf{C}$ appears independently of interactions with other factors in Figure 4, suggesting that a $\mathbf{C A}$ interaction may be responsible at least in part for the non-monotonic behavior of the $\mathrm{M}_{\mathrm{i}}{ }^{\mathrm{C}}$ in the Taguchi design of Table 3. Such behavior is consistent with previous observations of contributions of anion-film age interactions on current responses in paraquat-silicate thin film electrodes $[54,56]$. Interpretation of the non-monotonic behavior of the $\mathrm{M}_{\mathrm{i}}{ }^{\mathrm{H}}$ in Table 3 , however, is complicated by the combined effects of HA interactions, if any, and the HS interaction noted in Figure 4, which is of significant magnitude relative to the $\mathbf{H}$ Effect (i.e., -7.98 vs. -11.93 , respectively). Our results are unfortunately insufficient to resolve this issue.

The results from Figure 4 support a model of the general form shown in eq. (7) describing the current response of the 8 week old films in terms of the average system response and half the sum of the products of the significant Effects, E, and corresponding coded factors, F:

$\boldsymbol{i}=$ Average $+1 / 2 \Sigma_{\mathrm{j}}\left(\mathrm{E}_{\mathrm{j}}\right)\left(\mathbf{F}_{\mathrm{j}}\right)$

Using the appropriate values from Table 4 yields eq. (8) as a model for our 8 week old film electrodes in terms of the coded values of the statistically significant factors and factor interactions identified in Figure 4:

$\boldsymbol{i}=29.32+1 / 2[30.42 \mathbf{S}+13.15 \mathbf{L}-11.93 \mathbf{H}-7.98 \mathbf{H S}+6.91 \mathbf{C}+5.97 \mathbf{L S}]$

For an electrode comprising a fixed number of bilayers $(\mathbf{L})$ immersed in a solution of fixed acidity/pH $(\mathbf{H})$ operating at a constant scan rate $(\mathbf{S})$, eq. (8) correctly predicts a linear variation of current with chlorate concentration $(\mathbf{C})$ consistent with our observations in Figure $3 \mathrm{~B}$. The suitability of eq. (8) as a model equation for the electrodes can be further tested by calculating the differences between the currents measured in Table 4 and those calculated from eq. (8) using the coded values of each factor in each experiment (note Section III, Supplementary Material). The 16 residuals, $\Delta \mathrm{R}_{i}$, are summarized in Table 5 and assigned probabilities of occurrence due to random error, $P_{j}$, using eq. (9):

$P_{j}=100(j-1 / 2) / 16 \quad(j=1-16$ Residuals $)$ 
Table 5: Model Residuals

\begin{tabular}{|c|c|c|c|c|c|}
\hline Order & Residual $\left(\Delta \mathbf{R}_{i}\right)^{\mathbf{a}}$ & Probability $\left(\mathbf{P}_{\mathbf{j}}\right)$ & Order & Residual $\left(\Delta \mathbf{R}_{i}\right)$ & Probability $\left(\mathbf{P}_{\mathbf{j}}\right)$ \\
\hline 1 & -5.03 & 3.125 & 9 & 0.65 & 53.125 \\
\hline 2 & -3.27 & 9.375 & 10 & 1.44 & 59.375 \\
\hline 3 & -2.21 & 15.625 & 11 & 1.85 & 65.625 \\
\hline 4 & -1.96 & 21.875 & 12 & 1.90 & 71.875 \\
\hline 5 & -1.79 & 28.125 & 13 & 2.10 & 78.125 \\
\hline 6 & -1.33 & 34.375 & 14 & 2.10 & 84.375 \\
\hline 7 & 0.39 & 40.625 & 15 & 2.23 & 90.625 \\
\hline 8 & 0.52 & 46.875 & 16 & 2.41 & 96.875 \\
\hline
\end{tabular}

a Calculated based on eq. (8) using the reverse Yates' Algorithm (note Table S-8, Supplementary Material).

The corresponding normal probability plot of the $\Delta \mathrm{R}_{i} v s . \mathrm{P}_{\mathrm{j}}$ is shown in Figure 5. The plot is reasonably linear, with a range of $\Delta \mathrm{R}_{i}$ (i.e., $-5.03 \mu \mathrm{A} \leq \Delta \mathrm{R}_{i} \leq 2.41 \mu \mathrm{A}$ ) approximately $10 \%$ that of the measured net currents (i.e., $6.98 \mu \mathrm{A} \leq \boldsymbol{i}_{\text {ave }} \leq 69.74 \mu \mathrm{A}$ ) from Table 4. Consequently, eq. (8) provides a reasonable first approximation for the dependence of the current response on the statistically significant Effects and factors identified by the two-level factorial design.

\subsection{Conclusions}

We have demonstrated here that adaptation of a previously described multilayer film, prepared via layer-by-layer deposition of cationic para-rosaniline acetate dye (i.e., PR) and the vanadiumcontaining Keggin-type $\left[\mathrm{PMo}_{11} \mathrm{VO}_{40}\right]^{5-}$ (i.e., $\mathrm{PVMo}_{11}$ ) polyoxometalate anion, on indium tin oxide (ITO) provides an electrode for detection of chlorate. Taguchi L16 array and two-level full factorial statistically designed experiments were used to probe the current response as a function of the composition of the electrode and analyte solution. Performance was investigated as functions of the number of $\mathrm{PVMo}_{11} / \mathrm{PR}$ electrode bilayers ( $\mathbf{L} ; 3-6$ bilayers), solution acidity/pH $(\mathbf{H} ; \mathrm{pH} \sim 1.32-2.85)$, solution $\left[\mathrm{ClO}_{3}^{-}\right](\mathbf{C} ; 250-1000 \mu \mathrm{M})$, voltage scan rate $(\mathbf{S}$; $\left.50-200 \mathrm{mV} \cdot \mathrm{s}^{-1}\right)$, and film age (A; 1-8 weeks).

The Taguchi L16 array results indicated that maximum current response was obtained using 1 week old electrodes comprising $5 \mathrm{PVMo}_{11} / \mathrm{PR}$ bilayers scanned at $200 \mathrm{mV} \cdot \mathrm{s}^{-1}$ in $\mathrm{pH} 2.85$ solutions containing $1000 \mu \mathrm{M} \mathrm{ClO}_{3}{ }^{-}$. However, a significant film aging effect was also observed, consistent with relaxation of film components kinetically trapped during initial deposition to their equilibrium thermodynamic conformations with time, a process requiring at least 5 weeks at room temperature. Our results (note Figure S1B) suggest that relaxation is largely complete after 8 weeks of aging, at which point reproducible current measurements reflecting sample chlorate concentration can be obtained.

A subsequent two-level full factorial design investigation of the effects due to the $\mathbf{L}, \mathbf{H}, \mathbf{C}$, and $\mathbf{S}$ variables using 8 week old films identified the $\mathbf{L}, \mathbf{S}, \mathbf{H}$, and $\mathbf{C}$ factors and $\mathbf{H S}$ and $\mathbf{L S}$ factor interactions as making statistically significant contributions to the observed current. A model describing the dependence of electrode current on the levels of these parameters was derived, which included and confirmed the linear dependence on $\left[\mathrm{ClO}_{3}{ }^{-}\right]$noted in our early experiments. 
A key finding of this work was the insensitivity of the film/electrode to oxygen and common explosives such as TNT, which typically exhibit electrochemical signatures in the same region as the chlorate reduction and the polyoxometalate component of our films. In fact, linear dependence of current on chlorate concentration over a $0 \mu \mathrm{M} \leq\left[\mathrm{ClO}_{3}{ }^{-}\right] \leq 1000 \mu \mathrm{M}$ range in aerated $0.10 \mathrm{M}$ sodium acetate $\mathrm{pH} 2.5$ (aq) solution was demonstrated with a detection limit of $220 \mu \mathrm{M} \mathrm{ClO}_{3}{ }^{-}(\mathrm{S} / \mathrm{N}>3)$. The ability to determine chlorate under ambient conditions in this manner and the insensitivity of the electrode to the presence of common $\mathrm{N}$-based explosives bodes well for its eventual use in the field as a new tool to assist forces in the identification of IED manufacturing sites utilizing chlorate-based explosives. Work is currently in progress to understand and quantitatively map the effects of other environmental factors, such as temperature and humidity, on electrode preparation, storage, and performance and integrate the electrode system for deployment on unmanned aerial vehicle (UAV) platforms.

Acknowledgments: This work was supported by the US Naval Research Laboratory, and the Office of Naval Research for funding through an NRL 6.2 Program.

\section{References}

[1] S. Almaviva, R. Chirico, M. Nuvoli, A. Palucci, F. Schnurer, W. Schweikert, A new eye-safe UV Raman spectrometer for the remote detection of energetic materials in fingerprint concentrations: Characterization by PCA and ROC analyzes, Talanta, 144(2015) 420-6.

[2] Y.H. Guo, X.T. Wang, B. Miao, Y. Li, W.R. Yao, Y.F. Xie, J.D. Li, D.M. Wu, R.J. Pei, An AuNPs-functionalized AlGaN/GaN high electron mobility transistor sensor for ultrasensitive detection of TNT, RSC Adv, 5(2015) 98724-9.

[3] A.K.M. Jamil, E.L. Izake, A. Sivanesan, R. Agoston, G.A. Ayoko, A homogeneous surfaceenhanced Raman scattering platform for ultra-trace detection of trinitrotoluene in the environment, Anal Methods, 7(2015) 3863-8.

[4] N.V. Komarova, M.S. Andrianova, O.V. Gubanova, E.V. Kuznetsov, A.E. Kuznetsov, Development of a novel enzymatic biosensor based on an ion-selective field effect transistor for the detection of explosives, Sens Actuator B-Chem, 221(2015) 1017-26.

[5] B.C. Giordano, C.R. Field, B. Andrews, A. Lubrano, M. Woytowitz, D. Rogers, G.E. Collins, Trace explosives vapor generation and quantitation at parts per quadrillion concentrations, Anal Chem, 88(2016) 3747-53.

[6] B. Chiswell, B. Keller-Lehmann, Spectrophotometric method for the determination of chlorite and chlorate, Analyst, 118(1993) 1457-9.

[7] B.R. Deshwal, H.-K. Lee, Kinetics and mechanism of chloride based chlorine dioxide generation process from acidic sodium chlorate, J Hazard Mater, 108(2004) 173-82.

[8] B.R. Deshwal, H.K. Lee, Manufacture of chlorine dioxide from sodium chlorate: State of the art, J Ind Eng Chem, 11(2005) 330-46.

[9] A.N. Pisarenko, B.D. Stanford, O. Quinones, G.E. Pacey, G. Gordon, S.A. Snyder, Rapid Analysis of Perchlorate, Chlorate, and Bromate Ions in Concentrated Sodium Hypochlorite Solution, Anal Chim Acta, 659(2010) 216-23.

[10] R.J. Garcia-Villanova, C.R. Funcia, M. Leite, I.M.T. Fonseca, M. Espinosa, J.E. India, Direct injection ion chromatography for the control of chlorinated drinking water: simultaneous 
estimation of nine haloacetic acids and quantitation of bromate, chlorite and chlorate along with the major inorganic anions, J Water Health, 12(2014) 443-51.

[11] E.A. Burns, Spectrophotometric determination of chlorate impurities in ammonium perchlorate.Determination of reducing and oxidizing impurities in hydrochloric acid, Anal Chem, 32(1960) 1800-3.

[12] P. Urone, E. Bonde, Colorimetric determination of chlorates in well waters, Anal Chem, 32(1960) 1666-8.

[13] N.L. Trautwein, J.C. Guyon, Spectrophotometric determination of chlorate ion, Anal Chim Acta, 41(1968) 275-82.

[14] S.G. Hosseini, S.M. Pourmortazavi, K. Gholivand, Spectrophotometric determination of chlorate ions in drinking water, Desalination, 245(2009) 298-305.

[15] A.P. Oliveira, R.B. Faria, The chlorate-iodine clock reaction, J Am Chem Soc, 127(2005) 18022-3.

[16] M. Galajda, G. Lente, I. Fábián, Photochemically induced autocatalysis in the chlorate ion-iodine system, J Am Chem Soc, 129(2007) 7738-9.

[17] R.T.P. Sant'Anna, E.V. Monteiro, J.R.T. Pereira, R.B. Faria, The ozone-iodine-chlorate clock reaction, PLoS One, 8(2013) Article No. e83706.

[18] R.T.P. Sant'Anna, R.B. Faria, The chlorate-iodine-nitrous acid clock reaction, PLoS One, 9(2014) Article No. e109899.

[19] A.A. Rowe, A.J. Bonham, R.J. White, M.P. Zimmer, R.J. Yadgar, T.M. Hobza, J.W. Honea, I. Ben-Yaacov, K.W. Plaxco, CheapStat: an open-source, "do-it-yourself" potentiostat for analytical and educational applications, PLoS One, 6(2011).

[20] P.L. Buldini, D. Ferri, F. Zignani, Differential-pulse polarographic determination of traces of titanium in solar grade silicon, Fresenius Z Anal Chem, 314(1983) 660-4.

[21] J. Pelzer, F. Scholz, G. Henrion, P. Heininger, A reliable and ultrasensitive voltammetric method for the determination of molybdenum Fresenius Z Anal Chem, 334(1989) 331-4.

[22] K. Yokoi, C.M.G. van den Berg, Determination of titanium in sea water using catalytic cathodic stripping voltammetry, Anal Chim Acta, 245(1991) 167-76.

[23] M. Gawryś, J. Golimowski, Sensitive and very selective determination of titanium by adsorptive-catalytic stripping voltammetry with methylthymol blue, xylenol orange and calcein, Anal Chim Acta, 427(2001) 55-61.

[24] D. Krulic, N. Larabi, N. Fatouros, Process of the catalytic reduction of Ti(IV) in oxalatechlorate media, J Electroanal Chem, 579(2005) 243-7.

[25] A. Safavi, E. Shams, Selective determination of ultra trace concentrations of molybdenum by catalytic adsorptive stripping voltammetry, Anal Chim Acta, 396(1999) 215-20.

[26] Z. Gao, P. Li, Z. Zhao, Determination of iron(II) with chemically-modified carbon-paste electrodes, Talanta, 38(1991) 1177-84.

[27] Z. Gao, G. Wang, P. Li, Z. Zhao, Differential pulse voltammetric determination of cobalt with a perfluorinated sulfonated polymer-2,2-bipyridyl modified carbon paste electrode, Anal Chem, 63(1991) 953-7.

[28] Z. Gao, A. Ivaska, P. Li, Determination of Trace Amounts of Copper(I) with a Chemically Modified Carbon Paste Electrode, Anal Sci, 8(1992) 337-43.

[29] Z. Gao, K.S. Siow, Catalytic-adsorptive stripping voltammetric determination of molybdenum in plant foodstuffs, Talanta, 43(1996) 719-26.

[30] Z. Gao, K.S. Siow, A. Ng, Catalytic Voltammetric Determination of Molybdenum at a Chemically Modified Carbon Paste Electrode, Electroanalysis, 8(1996) 1183-7. 
[31] K. Unoura, A. Iwashita, E. Itabashi, N. Tanaka, Catalytic Effects of Chlorate Ions on the Electrode-reaction Processes of 12-Molybdophosphate and 12-Molybdosilicate, Bull Chem Soc Jpn, 57(1984) 597-8.

[32] M. Ikeda, K. Shimizu, G.P. Sato, A Ruthenium(IV)-ruthenium(III) Dimer product of the Reaction of Aqua(ethylenediaminetetraacetato)ruthenium(III) with Chlorate Ions, Bull Chem Soc Jpn, 55(1982) 797-801.

[33] L.G. Detusheva, L.I. Kuznetsova, V.A. Likholobov, Ruthenium complexes with heteropoly anion $\mathrm{PW}_{11} \mathrm{O}_{39}{ }^{7-}$ and their redox properties, Russ Chem Bull, 42(1993) 1294-300.

[34] O. Tue-Ngeun, J. Jakmunee, K. Grudpan, A novel stopped flow injection - Amperometric procedure for the determination of chlorate, Talanta, 68(2005) 459-64.

[35] S. Somnam, K. Grudpan, J. Jakmunee, Stopped-flow injection spectrophotometric method for determination of chlorate in soil, Mj Int J Sci Technol, 2(2008) 383-90.

[36] X.J. Xian, S.M. Wen, J.S. Deng, J. Liu, Q. Nie, Leaching chalcopyrite with sodium chlorate in hydrochloric acid solution, Can Metall Q, 51(2012) 133-40.

[37] G. Uçar, Kinetics of sphalerite dissolution by sodium chlorate in hydrochloric acid, Hydrometallurgy, 95(2009) 39-43.

[38] E.O. Olanipekun, R.A. Oderinde, The dissolution of galena in hydrochloric acid-chlorate solutions, Trans Indian Inst Met, 52(1999) 391-5.

[39] S. Sattar, K. Kustin, Role of osmium in the reaction of the hydrazinium cation with chlorate in acid solution, Inorg Chem, 30(1991) 1668-70.

[40] C. Castellani, Riduzione selettiva dei chloriti e del biossido di cloro con boroidruro di potassio in presenza di clorati, Bisi Ann Chim (Rome), 49(1959) 2057-9.

[41] L. Meites, H. Hofsass, Polarographic Determination of Chlorate, Anal Chem, 31(1959) 11922.

[42] H. Ohura, T. Imato, S. Yamasaki, Simultaneous potentiometric determination of $\mathrm{ClO}_{3} /^{-}-$ $\mathrm{ClO}_{2} /{ }^{-}$and $\mathrm{ClO}_{3} /-\mathrm{HClO}$ by flow injection analysis using $\mathrm{Fe}(\mathrm{III})-\mathrm{Fe}(\mathrm{II})$ potential buffer, Talanta, 49(1999) 1003-15.

[43] L. Nylén, J. Gustavsson, A. Cornell, Cathodic Reactions on an Iron RDE in the Presence of Y( III ), J Electrochem Soc, 155(2008) E136-E42.

[44] J. Gustavsson, L. Nylén, A. Cornell, Rare earth metal salts as potential alternatives to $\mathrm{Cr}$ (VI) in the chlorate process, J Appl Electrochem, 40(2010) 1529-36.

[45] D.M. Fernandes, A. Teixeira, C. Freire, Multielectrocatalysis by Layer-by-Layer Films Based on Pararosaniline and Vanadium-Substituted Phosphomolybdate, Langmuir, 31(2015) 1855-65.

[46] S. Himeno, N. Ishio, A voltammetric study on the formation of V(V)- and V(IV)-substituted molybdophosphate(V) complexes in aqueous solution, J Electroanal Chem, 451(1998) 203-9.

[47] M-S. Chen, S.L. Brandow, C.S. Dulcey, W.J. Dressick, G.N. Taylor, J.F. Bohland, J.H. Georger, E.K. Pavelchek, J.M. Calvert, Channel-constrained electroless metal deposition on ligating self-assembled film surfaces, J Electrochem Soc, 146(1999) 1421-30.

[48] J. Golden, L. Shriver-Lake, K. Sapsford, F. Ligler, A "do-it-yourself" array biosensor, Methods, 37(2005) 65-72.

[49] G. Zolfaghari, A. Esmaili-Sari, M. Anbia, H. Younesi, S. Amirmahmoodi, A. GhafariNazari, Taguchi optimization approach for $\mathrm{Pb}$ (II) and $\mathrm{Hg}$ (II) removal from aqueous solutions using modified mesoporous carbon, J Hazard Mater, 192(2011) 1046-55.

[50] G.E.P. Box, W.S. Hunter, J.S. Hunter, Statistics for Experimenters: An Introduction to Design, Data Analysis, and Model Building, New York, NY: John Wiley \& Sons, Inc.; 1978. 
[51] D. Bonenfant, M. Mimeault, R. Hausler, Determination of the Structural Features of Distinct Amines Important for the Absorption of $\mathrm{CO} 2$ and Regeneration in Aqueous Solution, Ind Eng Chem Res, 42(2003) 3179-84.

[52] D.M. Fernandes, C. Freire, Hybrid Photochromic Multilayers Based on Chitosan and Europium Phosphomolybdate, J Appl Electrochem, 44(2014) 655-65.

[53] D.C. Harris, Quantitative chemical analysis, 7th ed., New York, NY: W.H. Freeman and Co.; 2007.

[54] N. Lebedev, S.A. Trammell, W. Dressick, G.S. Kedziora, I. Griva, J.M. Schnur, Structural Reorganizations Control Intermolecular Conductance and Charge Trapping in ParaquatTetraphenylborate Inverse Photoelectrochemical Cell, Photochem Photobiol, 87(2011) 1024-30. [55] S.A. Trammell, W.J. Dressick, B.J. Melde, M. Moore, Photocurrents from the Direct Irradiation of a Donor-Acceptor Complex Contained in a Thin Film on Indium Tin Oxide, J Phys Chem C, 115(2011) 13446-61.

[56] S.A. Trammell, S. Tsoi, B. Martin, B.J. Melde, M.M. Moore, W.J. Dressick, Directional Photoinduced ElectronTtransfer in Paraquat Silicate Thin Films Containing Entrapped Ruthenium(II)-tris(bathophenanthroline-disulfonate), Chem Commun, 47(2011) 11348-50.

[57] V.V. Lulevich, S. Nordschild, O.I. Vinogradova, Investigation of molecular weight and aging effects on the stiffness of polyelectrolyte multilayer microcapsules, Macromolecules, 37(2004) 7736-41.

[58] L. Richert, A.J. Engler, D.E. Discher, C. Picart, Elasticity of native and cross-linked polyelectrolyte multilayer films, Biomacromolecules, 5(2004) 1908-16.

[59] O.I. Vinogradova, Mechanical properties of polyelectrolyte multilayer microcapsules, J Phys-Condens Matter, 16(2004) R1105-R34.

[60] K.E. Secrist, A.J. Nolte, Humidity Swelling/Deswelling Hysteresis in a Polyelectrolyte Multilayer Film, Macromolecules, 44(2011) 2859-65.

[61] S. Dong, W. Jin, Study of a 1:12 Phosphomolybdic Anion Doped Polypyrrole Film Electrode and its Catalysis, J Electroanal Chem, 354(1993) 87-97.

[62] G. Xue, J. Xiong, H. Guo, G. Cao, S. Nie, H. Hu, Two new inorganic-organic hybrids based on Keggin polyoxometalate and methylene blue and application in chemically bulk-modified electrode, Electrochim Acta, 69(2012) 315-9.

[63] Hydrochloric acid $(\mathrm{HCl})$ and chloric acid $\left(\mathrm{HClO}_{3}\right)$ are strong acids $\left(\mathrm{pK}_{\mathrm{a}}<-1\right)$, precluding proton association with chloride or chlorate ions as a potential mechanism for proton transport into the films under our $\mathrm{pH}$ conditions.

[64] The negative contribution in this case is expected because the $\mathbf{H}$ factor in the Taguchi design is defined in terms of low vs. high $\mathrm{pH}$, whereas in the Factorial design $\mathbf{H}$ is defined in terms of low vs. high solution acidity. That is, the definition of the $\mathbf{H}$ factor in the factorial design is opposite that of the Taguchi design, with weaker acidity (i.e., high $\mathrm{pH}$ ) defined as the low (i.e., -1) level and stronger acidity (i.e., lower pH) defined as the high (i.e., +1) level for the coded $\mathbf{H}$ factor. 


\section{Figure Captions}

Scheme 1. Layer by layer (LbL) alternate electrostatic deposition of the Keggin-type polyoxometalate anion, $\left[\mathrm{PMo}_{11} \mathrm{VO}_{40}\right]^{5-}\left(\mathrm{PMo}_{11} \mathrm{~V}\right)$, and the cationic dye, $p$-rosaniline acetate $(\mathrm{PR})$ on ITO.

Figure 1 A. Absorbance spectra as a function of number of deposited $\mathrm{PVMo}_{11} / \mathrm{PR}$ bilayers. Spectra in order of increasing absorbance at $535 \mathrm{~nm}$ are shown for 1, 2, 3, 4, 5, 6, 8, 10, 12 14, 16, 18, and 20 bilayers. B. Para-rosaniline absorbance at $535 \mathrm{~nm} \mathrm{vs}$. number of $\mathrm{PVMo}{ }_{11} / \mathrm{PR}$ bilayers deposited. Two linear fits of the data are shown. The data from $n=0-6$ obey the equation: $\mathrm{A}=0.0053 \mathrm{n}+0.002, \mathrm{r}^{2}=0.9907$. The data from $n=6-20$ obey the equation: $\mathrm{A}=$ $0.0078 n-0.0164, r^{2}=0.9973$.

Figure 2 A. Cyclic voltammograms of $\mathrm{PVMo}_{11} / \mathrm{PR}$ bilayers $(n=6)$ on ITO as a function scan rate. B. Peak currents $v s$. scan rate at $\mathrm{I}_{\mathrm{pc}}=-0.255 \mathrm{~V} v s . \mathrm{Ag} / \mathrm{AgCl}$ and $\mathrm{I}_{\mathrm{pa}}=-0.205 v s . \mathrm{Ag} / \mathrm{AgCl}$. Buffer $=$ aerated $100 \mathrm{mM}$ sodium acetate $\mathrm{pH} 2.5$.

Figure 3 A. Cyclic voltammograms of $\mathrm{PVMo}{ }_{11} / \mathrm{PR}$ bilayers on ITO with increasing $\left[\mathrm{KClO}_{3}\right]$ concentration. B. Current vs. $\left[\mathrm{KClO}_{3}\right], \mu \mathrm{M}$ (at $-0.4 \mathrm{~V}$. vs. $\mathrm{Ag} / \mathrm{AgCl}$ ) in aerated $100 \mathrm{mM}$ sodium acetate buffer $\mathrm{pH}$ 2.5. Scan rate $=50 \mathrm{mV} \cdot \mathrm{s}^{-1}$. Error bars are the standard deviation with $\mathrm{n}=3$.

Figure 4: Normal Probability Plot of Effects: Plot of current Effects from Table 4 vs. probability of random occurrence, $\mathrm{P}_{\mathrm{j}}$. Effects comprising the straight line portion of the plot are ascribed to random error. The Effects deviating from the line make statistically significant contributions to the observed current. Letters identify the factor or factor interactions corresponding to each point.

Figure 5: Normal Probability Plot of Current Residuals: Plot of current residuals $\left(\Delta \mathrm{R}_{i}\right)$ from Table 5 vs. probability of random occurrence, $\mathrm{P}_{\mathrm{j}}$. 
Scheme 1

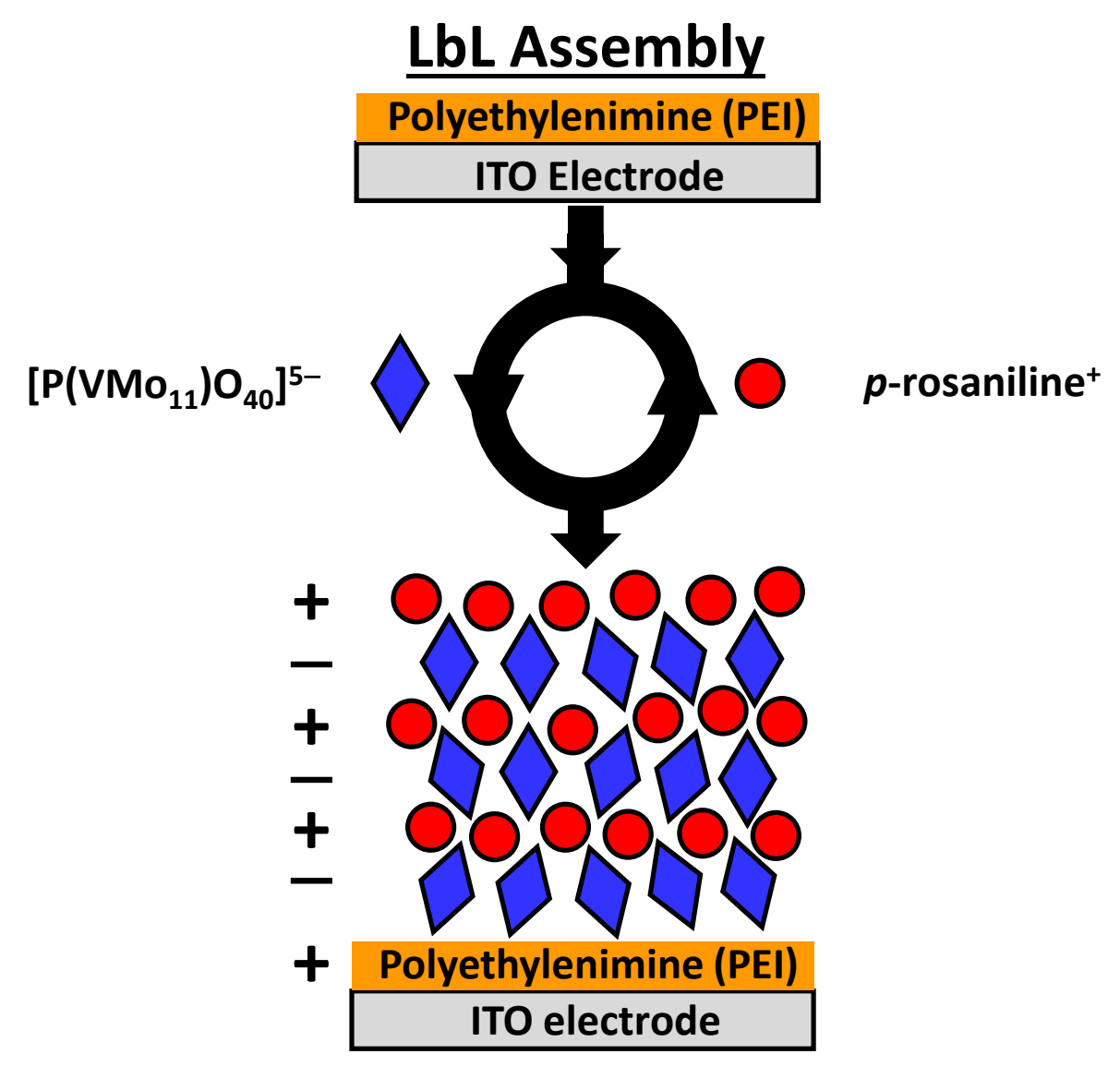


Figure 1

A

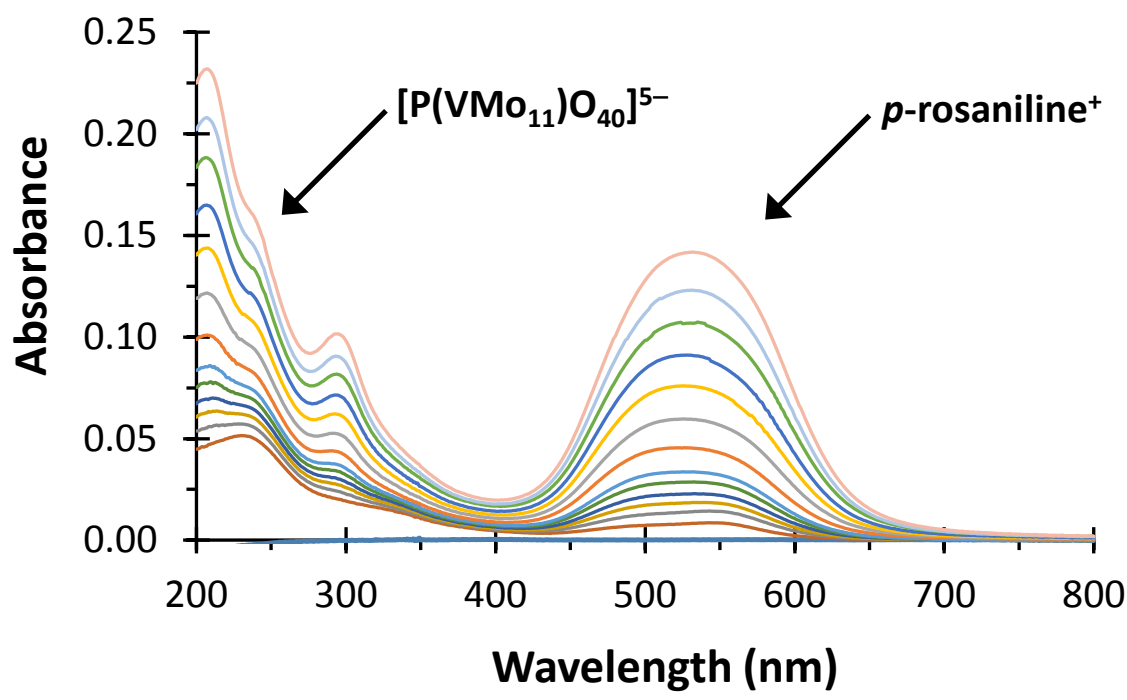

B

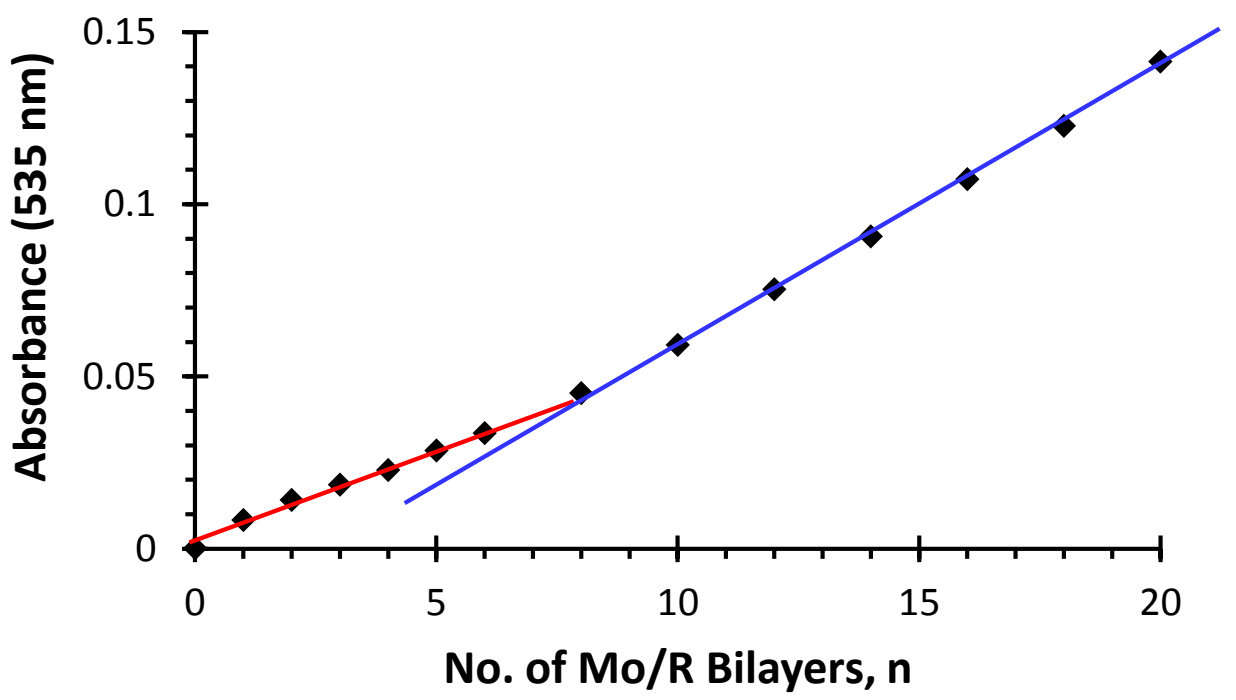



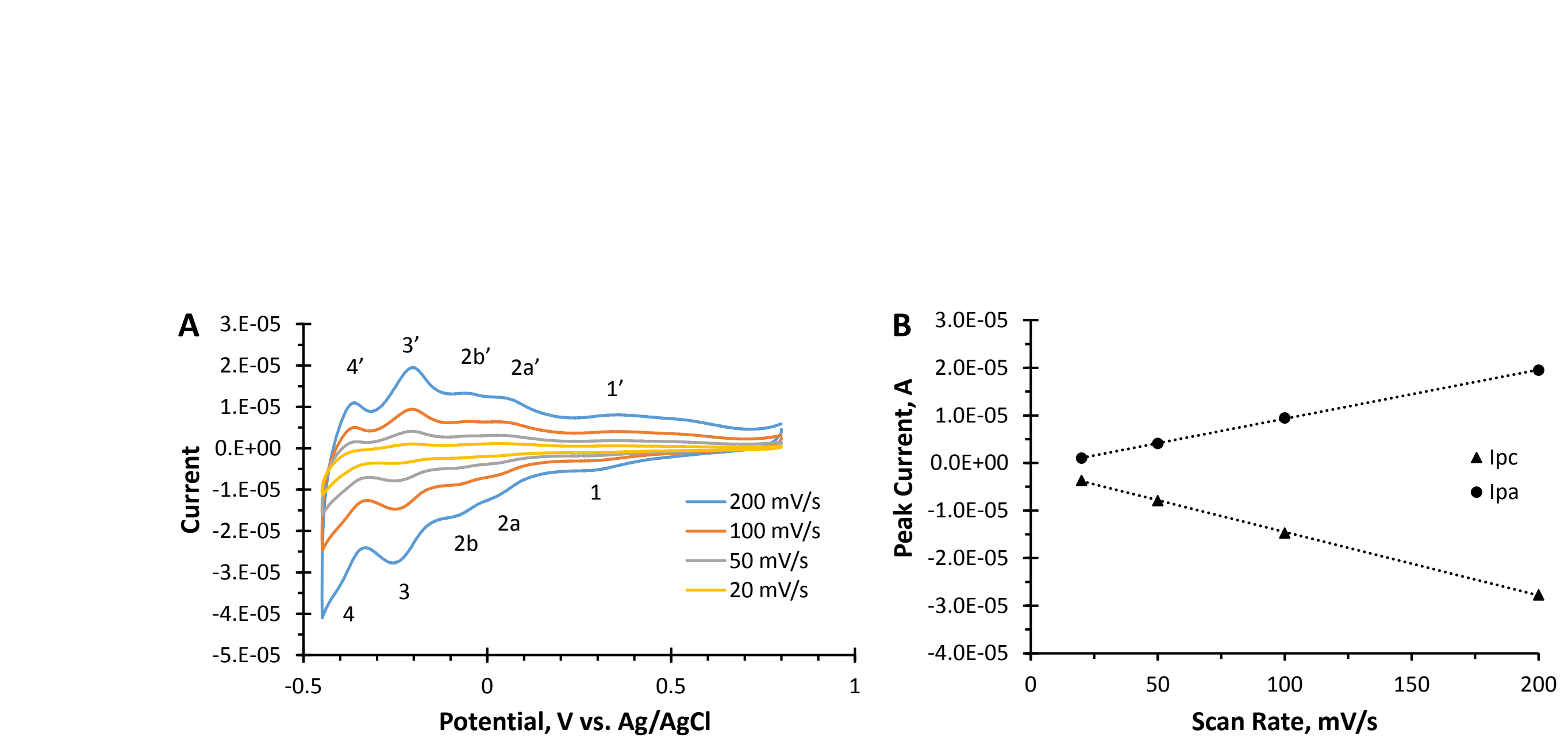

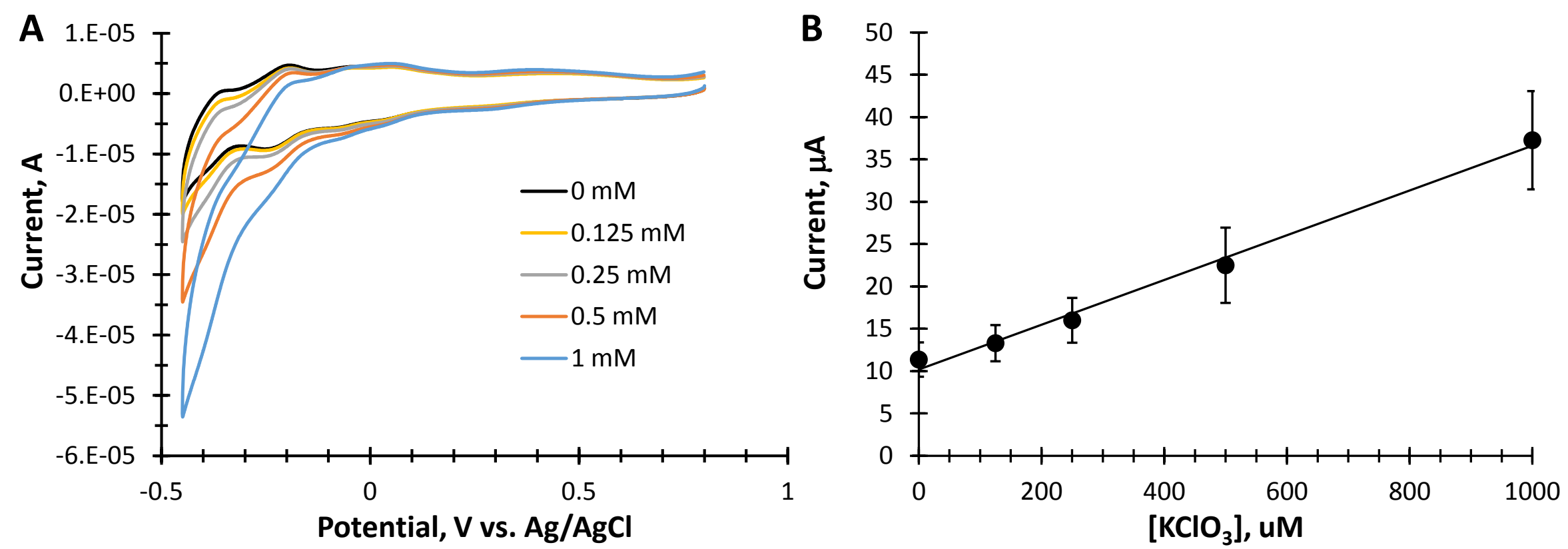


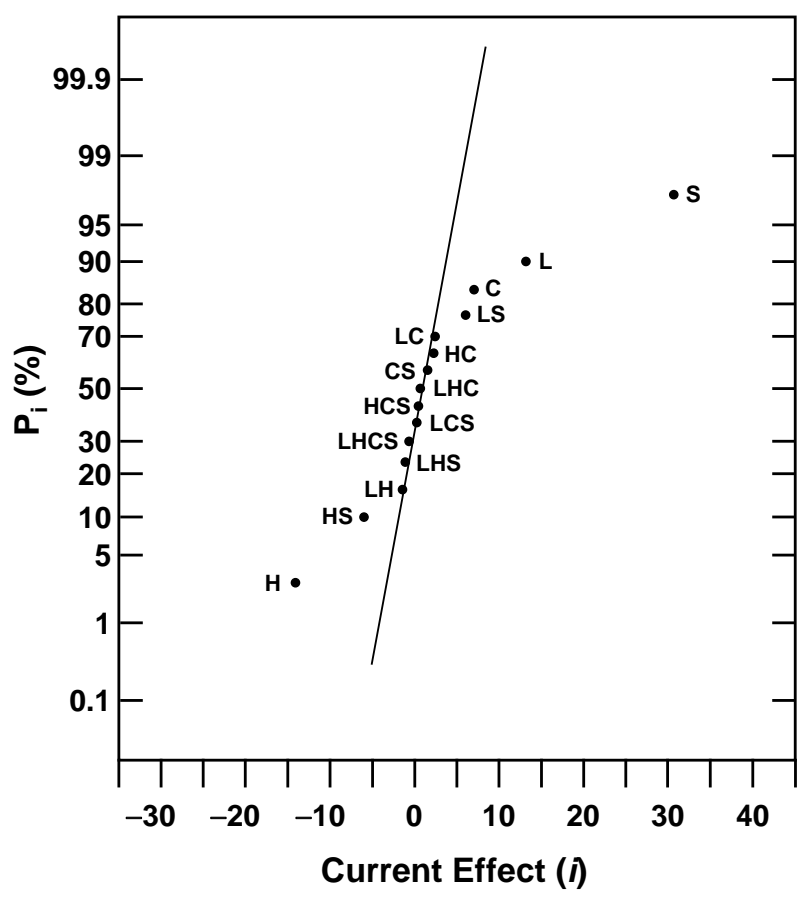

Current Effect (i) 


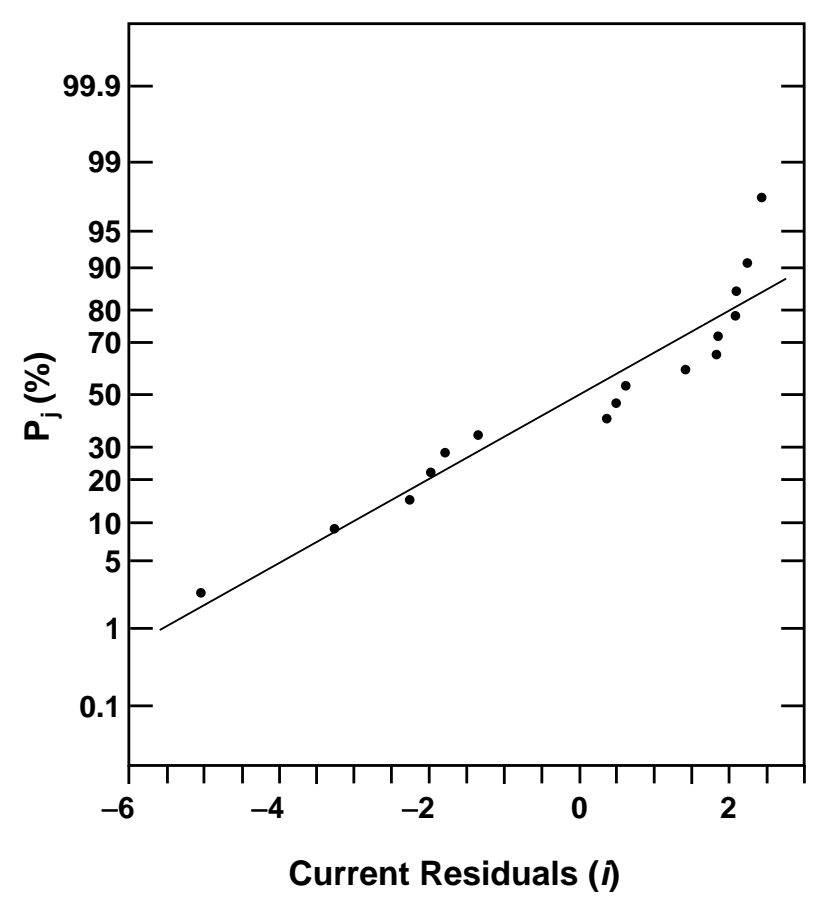

Current Residuals (I) 


\section{Biographical sketches}

Scott A. Trammell earned a B.A. in chemistry from the University of Northern Colorado and a $\mathrm{PhD}$ in inorganic chemistry from the University of Wyoming. He has completed two postdoctoral fellowships; at the University of North Carolina in Chapel Hill and at the Naval Research Laboratory as a NRC fellow. His background ranges from inorganic photochemistry and electrochemistry to synthetic skills. He has held a federal position at the Naval Research Laboratory since 2001. Currently, he is addressing fundamental issues involving photoinduced electron transfer in thin films for applications in solar cells, developing new sensing schemes for explosives detection and exploiting the properties of metal nanoparticles for basic research ranging from enhanced catalysis to gamma ray detection.

Lisa C. Shriver-Lake received her BS in animal science degree in 1979 from the University of Maryland at College Park and a MS in chemistry from George Mason University, Fairfax, VA, in 1991. Ms. Shriver-Lake has been at the Naval Research Laboratory for over 30 years performing many aspects of analytical and bioanalytical sciences, and protein immobilization. She has significant expertise in biosensor development including assay development for bacteria, toxins, explosives and other small molecules in complex matrices, optical and electrochemical detection, and system optimization. Ms. Shriver-Lake also has expertise in laboratory and field research, data collection/analysis, and validation. Ms. Shriver-Lake has published over 65 refereed publications and 4 patents.

Walter J. Dressick received his B. Sci. in Chemistry (summa cum laude) in 1977 from the University of Pittsburgh. He was awarded a Ph.D. degree in Inorganic Chemistry in 1981 from the University of North Carolina at Chapel Hill (National Science Foundation Fellow) for his photocatalysis research exploiting electron transfer reactions of luminescent transition metal complex excited states. Dr. Dressick joined the Naval Research Laboratory (NRL) in Washington, DC in 1989 and is currently a Senior Research Chemist. His interests include development of non-covalent methods for the selective deposition of materials onto polymer and SAM films and electrodes, fabrication of nanostructured polymer films and composites exhibiting surface anisotropy (e.g., wetting, adhesion, friction), preparation of 3-D nanoscale metal structures using biological materials as reaction templates, and fabrication of 
nanostructured polyelectrolyte multilayer film composites for use as improved fuel cell electrodes, sensors, and self-decontaminating coatings. 